\title{
Információ és az információs társadalom fogalma
}

Az itt közölt tanulmány a szerző „Az információs társadalom elméletei” című, 1997-ben megjelent kötetének 2. fejezete (Theories of the Information Society, London, Routledge). A szerző fő célja itt a következő kérdések felvetése: Amikor az emberek „információs társadalomról” beszélnek, vajon mit értenek ez alatt? Milyen kritériumokat nyújtanak ahhoz, hogy az „információs társadalmat” megkülönböztethessük más típusoktól? Az „információs társadalom” meghatározásai között analitikailag ötféle definíciót lehet megkülönböztetni, amelyek mindegyike kritériumokat tartalmaz annak azonosítására, ami új. Ezek a következő típusokba sorolhatók: technológiai, gazdasági, foglalkoztatási, tér-szemléletű és kulturális meghatározások. A fejezet második részében a szerző magának az „információnak” a különféle értelmezéseit elemzi, hangsúlyozva, hogy sohasem szabad lemondanunk az információ jelentését és rendeltetését firtató kérdésekről.

Kulcsszavak: információs társadalom, információ, az információs társadalom elméletei

\section{Szerzői információ:}

\section{Frank Webster}

Szociológusprofesszor alma matere a London School of Economics and Political Science (LSE). Számos egyetemen dolgozott az Egyesült Királyságban és más országokban. A Birminghami Egyetemen a Kultúraelméleti és Szociológiai Tanszék vezetôje volt, 2003 óta a City University szociológiai kurzusait irányítja. Oktatói és kutatói munkája során a mai társadalmi változásokkal, valamint az IKT társadalmi hatásaival foglalkozik. Kutatási témái az információs és kommunikációs trendek, a fogalmi analízis és kritika, a fejlett technológiáknak a könyvtárakra és az urbanizációra gyakorolt hatásai és az új médiumok. Szakmai konferenciák nemzetközi hírú, keresett előadója. Könyveit és tanulmányait sok nyelvre, köztük kínaira és japánra is lefordították. Információs háboruí c. legújabb könyvében (társszerzővel) a háborúellenes mozgalmak IKT-használatának témáját dolgozta fel.

E-mail: F.Webster@city.ac.uk

Igy hivatkozzon erre a cikkre:

Webster, Frank. „Információ és az információs társadalom fogalma”.

Információs Társadalom VII, 4. szám (2007): 7-35.

https://dx.doi.org/10.22503/inftars.VII.2007.4.1

A folyóiratban közölt müvek

a Creative Commons Nevezd meg! - Ne add el! - Így add tovább! 4.0

Nemzetközi Licenc feltételeinek megfelelöen használhatók. 
Frank Webster

\section{Információ és az információs társadalom fogalma}

Megjelent a szerző „Az információs társadalom elméletei”

(Theories of the Information Society) címú kötetében, 2. fejezet. London, 1997, Routledge.

Mielótt megfelelôen értékelhetnénk a mostanában megfigyelhetô információs trendek és jelenségek eltérố megközelítéseit és értelmezéseit, figyelmet kell szentelnünk a viták résztvevớitól származó különféle definícióknak. Azt hiszem, különösen hasznos lehet, ha már a kiinduláskor megvizsgáljuk, hogy az információs társadalom mindenütt fellelhető szószólói voltaképpen mire gondolnak, amikor ezt a terminust használják. Azoknak a kitartó ragaszkodása ehhez a kifejezéshez, akik szívesen élnek vele, és az a magabiztos állításuk, hogy korunk egyik fó jellemzốje nem más, mint az újdonsága, sürgetốen elemzés után kiált - talán még annál is sürgốsebben, mint azoknak a forgatókönyvei, akik szerint minden változatlan marad. E fejezet fö célja a következő kérdések felvetése: Amikor az emberek információs társadalomról beszélnek, vajon mit értenek ezen? Milyen kritériumokat nyújtanak ahhoz, hogy az információs társadalmat megkülönböztethessük más típusoktól? Amikor megvizsgálom az információs társadalom elméleteit, természetesen tekintetbe kell vennem azoknak a szempontjait is, akik elutasítják ezt a kifejezést, hiszen az információs társadalom eszméjének legtöbb kritikája magában foglalja a bírálók kételyeinek kifejezését.

Késóbb túllépek az információs társadalom meghatározásainak vizsgálatán, és magának az „információnak” a különféle értelmezéseit elemzem. Mint látni fogjuk, itt éppen az összes vita középpontjában álló kulcsfogalom értelmezésében - jelentôs különbségek vannak, amelyekben visszatükrözôdik az információs társadalom újszerúségét hangsúlyozó teoretikusok és az „informatizálódás” azon gondolkodói között fennálló szakadék, akik felismerik, hogy a múlt ereje súlyosan kihat a mai fejleményekre.

\section{AZ INFORMÁCIÓS TÁRSADALOM MEGHATÁROZÁSAI}

Az információs társadalom meghatározásai között analitikailag ötféle definíciót lehet megkülönböztetni, amelyek mindegyike kritériumokat tartalmaz annak azonosítására, ami új. Ezek a következő típusokba sorolhatók: technológiai, gazdasági, foglalkoztatási, térszemléletú és kulturális meghatározások.

Ezeknek természetesen kölcsönösen egymást kizárónak kell lenniük (lásd például Dordick és Wang 1993), habár - mint látni fogjuk - egyes teoretikusok a saját forgatókönyvük bemutatásakor más-más tényezóket hangsúlyoznak. Vegyük szemügyre közelebbról ezeket a meghatározásokat! 


\section{Technológiai meghatározások}

Az információs társadalom leggyakoribb definíciója a látványos technológiai innovációra helyezi a hangsúlyt. A kulcsgondolat az, hogy az információ feldolgozása, tárolása és továbbítása terén történt áttörések az információs technológiák (ITT) széles körú alkalmazásához vezettek a társadalom gyakorlatilag valamennyi szegmentumában. A fớ kérdés itt a számítógépek árának megdöbbentố csökkenése, teljesítményük csodálatra méltó növekedése, és ebból következóen kiterjedt alkalmazásuk bárhol és mindenütt (Office of Technology Assessment, 1990, 46). Mivel ma lehetséges és gazdaságos számítógépeket építeni be az írógépekbe, az autókba, a tûzhelyekbe, az órákba, az üzemekben múködố gépekbe, a televíziókba és a gyermekjátékokba, következésképpen minden bizonnyal olyan nagyságrendú társadalmi változásokat fogunk tapasztalni, melyek révén új korszakba lépünk. Könyvek, magazinokban megjelent cikkek és televízió-músorok sokasága ösztönözte és ösztönzi egy új típusú emberfajta kifejlôdését, melynek egyedei meg vannak gyốzốdve arról, hogy a „nagyhatalmú mikrocsip” valami egészen újszerú „szilíciumcivilizáció" beköszöntét hirdeti.

Az információs társadalom meghatározásához vezetố technológiai megközelítések kissé kifinomultabb változatai figyelmet fordítanak a távközlés és a számítástechnika konvergenciájára és átfedéseire is. Ezekben az esetekben a gondolatmenet a következő vonalat követi: az olcsó információfeldolgozási és információtárolási technológiák (a számítógépek) fejlődése ahhoz vezet, hogy ezek igen széles körben elterjednek. Egyik legfóbb alkalmazási területük a távközlés, különös tekintettel a kapcsolóközpontokra, amelyekben - ha számítógépesítik óket - ténylegesen összeolvad a távközlési rendszerek és a számítástechnikai eszközök fejlődése, és ennek eredményeként még erốteljesebb fejlődés következik be az információ kezelése és terjesztése terén. Ez az egységesedés különösen váratlan fejlemény, mivel a számítógépek széles körú elterjedése azzal jár együtt, hogy optimális használatukhoz összeköttetésekre van szükség közöttük. Röviden: a távközlés számítógépesítése következtében egyre inkább az a helyzet, hogy a számítógépek más számítógépekhez kapcsolódnak, ebból pedig az a kilátás adódik, hogy a terminálok összeköttetésbe kerülnek egymással, vagyis új kapcsolatok jönnek létre a hivatalok, a bankok, az otthonok, az üzletek, a gyárak és az iskolák között és az egyes intézményeken belül is.

A hálózatba kötött számítógépek világának ezt a forgatókönyvét gyakran az elektromos áramszolgáltatáshoz hasonlítják: az ,információs hálózat”* múködése analógiába állítható az elektromos áramellátással. Mint ahogyan az elektromos hálózat összeköt minden otthont, irodát, gyárat és üzletet azáltal, hogy energiát szolgáltat számukra, az információs hálózat ugyanígy információt szolgáltat mindenütt, ahol arra szükség van. Ez természetesen evolúciós folyamat, az integrált szolgáltatások digitális hálózatának (Integrated Services Digital Network, ISDN) kialakulása révén azonban máris használjuk az információs társadalom alapvetố elemeit.

* Az 1995-ben írt eredeti szövegben az ,information grid” kifejezés szerepel, melynck a pontos fordítása „információs rács” volna, helyesebbnck tűnik azonban a ma közkeletűvé vált „hálózat” kifejezést használni, annál is inkább, mert az angol nyelvben a ,grid" (rács) szóval az országos elcktromos hálózator jelölik. - $A$ ford. 
Az információs hálózat csatornái, miután létrejöttek, a modern kor legfóbb közlekedési útjaivá válnak, hasonlóan az ipari korszak közútjaihoz, vasútvonalaihoz és csatornáihoz. Mint ahogyan az utóbbiak döntô fontosságú szerepet játszottak, mivel rajtuk szállították minden irányban azokat az anyagokat és árucikkeket, amelyek létrehozták az ipari forradalmat, ugyanúgy az ISDN fogja biztosítani az alátámasztó infrastruktúrát az információs társadalom számára.

Kétségtelen, hogy itt technológiai alapon történt az információs társadalom meghatározása, amely akár drámaian új technológiai innovációk, akár az ehhez többletként megjelenố $I S D N$-rendszerek hatásának az eredményeként születik meg: az új rend fó megkülönböztetố jegye mindkét esetben a technológia.

Az információs társadalom technológiai megközelítéseinek elutasítására nagy a kísértés. El vagyunk árasztva álmélkodó és rácsodálkozó írásokkal, amelyek a technológiai változás sebességétól és nagyságrendjétól lenyưgözve, naivan azt mondják nekünk, hogy „a számítógépek forradalma [...] mindent átfogó, elemi erejú hatásokat fog kifejteni, befolyásolva minden egyes emberi lényt a Földön, életének valamennyi aspektusában" (Evans 1979, 13). Egyes futurológusok átvették ezt a hangnemet, s írásaik jellemzó módon tele vannak „ébresztố” célzatú vészjelzésekkel, a valóság birodalmának sekélyes elemzéseivel és túlzott önbizalommal, azt sugallva, hogy csupán a szerző értette meg azt, amit majdnem mindenki másnak még ezután kell felfognia. Ez a fajta megközelítés aligha támasztja alá hathatósan a technológiai mércék érvényességét (Webster és Robins 1986, 2. fejezet).

Mindazonáltal tudomásul kell vennünk, hogy igen sok komoly tudós munkáit gyökerében hasonló felfogás jellemzi, még akkor is, ha egyes írók - például Alvin Toffler és James Martin - arra ösztönöznek bennünket, hogy minden további nélkül vessük el a technológiai kritériumokat. Nagy-Britanniában például egy igen tekintélyes elméleti iskola kidolgozta a változások neo-schumpeteriánus megközelítését. Azt a schumpeteri gondolatot, hogy a fóbb technológiai innovációk „kreatív rombolással” járnak, ezek a kutatók kombinálják Kondratyevnek a gazdasági fejlődés „hosszú hullámairól" szóló tézisével, és arra a következtetésre jutnak, hogy az információs technológia új korszak kialakulásának a letéteményese. Ez az új „techno-ökonómiai paradigma” (Freeman és Perez 1988) hozza létre az „információ korát”, amely a következő évszázad elején fog beérni (Hall és Preston 1988; Freeman 1987; Freeman et al. 1982).

Michael Piore és Charles Sabel (1984) azt állítja, hogy az új technológiák alapot nyújtanak a munkavégzés radikálisan új módjára, a „rugalmas specializálódásra”. A kommunikációs és számítógépes technológiák információs előnyt biztosítanak a kisméretú vállalatok számára, amelyek ennek köszönhetôen immár képesek gyorsan felmérni a piacokat és rugalmasan alkalmazkodni az igényekhez. Következésképpen láthatóvá válik a „tömegtermelés” vége, és küszöbön áll a tömegcikkek sokoldalúan képzett és alkalmazkodóképes szakemberek által testre szabott, nagyrészt egyedileg gyártott termékekkel való felváltása.

El kell ismernünk, hogy az információs társadalom technológiai meghatározásai józan ésszel mérlegelve - megfelelớnek túnnek. Végül is, ha az „ipari társadalom” kulcsjellemzójének a „találmányok sorozatát” (Landes 1969) tekinthetjük, akkor miért ne fogadhatnánk el az IT káprázatos fejlődését egy új típusú társadalom kialakulásának alapjaként? Ahogy John Naisbitt megfogalmazza: „a számítógépes technológia ugyanaz 
az információs kor számára, mint ami a gépesítés volt az ipari forradalom szempontjából” (1984, 28). Ám vizsgáljuk meg azt is, hogy mi szól ez ellen!

Az információs társadalom technológiai definícióival kapcsolatban legalább két jól megalapozott kifogást kell tennünk.

Amikor az új technológia által elindított és a jövóben tóle várható rendkívüli és mélyreható változásokról szóló irodalmat olvassuk, nem tagadhatjuk, hogy ennek a technológiának a jelenléte mindannyiunk számára máris megdöbbentôen érzékelhetô és kitapintható. Akár a „mikroelektronikai forradalomnak” az otthonokra, illetve a numerikus számítógépi vezérlésre (Computer Numerical Control, CNG) épülő technológiának a termelési folyamatokra gyakorolt hatásairól, akár a számítógépek, a telekommunikáció és a biotechnológia „harmadik hullámának” elsöprố erejéról hallunk, ami „megkongatja az indusztrializmus fölött a lélekharangot, és egy új civilizáció születését hirdeti” (Toffler 1980, 2), az új technológiák jelenléte magától értetốdô valóság. Mivel ezt mindannyian láthatjuk a saját szemünkkel, nyilvánvalónak látszik, hogy a technológiákat indokoltan tekinthetjük egy új társadalom megkülönböztetó jegyeinek.

Amikor azonban mélyebbre hatolva vizsgálódunk, nem térhetünk ki az elól, hogy észrevegyük a technológia meghatározásának megdöbbentố mértékú bizonytalanságát a legtöbb ilyen könyvben. Ebben a társadalomban, ma, vagyis itt és most vajon mennyire van csakugyan jelen az IT, és mennyiben visz ez bennünket közelebb ahhoz, hogy megfeleljünk az információs társadalom státusának? Az IT milyen mértékú elterjedésére van szükség ahhoz, hogy megállapíthassuk az információs társadalom beköszöntét? Ha egyszerúen csak valamilyen használható mércét próbálunk találni, hamarosan tudatára ébredhetünk annak, hogy igen sokan azok közül, akik a technológia fontosságát hangsúlyozzák, nem képesek semmit sem nyújtani számunkra, ami ilyen hétköznapi módon, a valóságos világban kipróbálhatóan alkalmazható lenne. Kezdjük úgy érezni, hogy az IT valóban mindenütt jelen van... és ugyanakkor sehol sincs.

Ez a mérési probléma, valamint a hozzá társuló nehézségek annak a bizonyos pontnak valamilyen technológiai skálán való meghatározását illetôen, amelynek az elérésekor egy társadalom úgy ítélhetô meg, hogy belépett az információs korba, minden bizonnyal központi fontosságúak egy megkülönböztethetốen új típusú társadalom bármilyen elfogadható meghatározása szempontjából. Ezekról a gondokról a népszerú futurológusok nem vesznek tudomást: dicsôítik az új technológiákat, és gátlások nélkül feltételezik, hogy ezeknek az elterjedése magától értetódöen, önmagában is az információs társadalom beköszöntét jelenti. Meglepó módon megkerülik ezt a kérdést más tudósok is, akik azt állítják, hogy az I'T az információs társadalom legfóbb mutatója, de beérik azzal, hogy általánosságban leírják a technológiai innovációkat, feltételezve, hogy ez már elegendốaz új társadalom megkülönböztetéséhez.

Vannak azonban olyan tudósok is, akik nem elégednek meg ennyivel, és úgy találják, hogy a mérés problémája jelentős akadályt képez az előrehaladásban. Ők két különösen kellemetlen kérdéssel találják szemben magukat. Először is: Hogyan lehet megmérni a technológia elterjedésének mértékét? Másodszor: Mikor szúnik meg egy társadalom „iparinak” lenni, és mikor lép be az „információs” kategóriába? Ezek rendkívül nehéz kérdések, amelyeknek az információs társadalom lelkes szószólóit habozásra kell késztetniük. Nagy-Britanniában például az „Információs és kommunikációs technológiai program" (Programme on Information and Communication Teclinologies, PICI) 
keretében folyó társadalomtudományi kutatásoknak több mint egy évtizeden át az volt a feladatuk, hogy feltérképezzék és megpróbálják mérni az információs társadalom megvalósulását, ám mindeddig nem tudtak semmiféle meggyớző eredményt elérni (Miles és tsai. 1990). Amikor különféle vizsgálatok során felmérték bizonyos információs technológiák terjedését az üzemekben és az irodákban (például Northcott és Walling 1989), bizonyára voltak kézzelfogható eredményeik. Hogyan lehet azonban ezt a terjedést általánosabb érvénnyel is felmérni? Vajon az I'T-re fordított költségekkel? (Ám adottak lévén az új technológiák erôsen változó költségei, hogyan lehet elválasztani a gazdasági változókat az információkezelési teljesítménł centrálisabb jelentôségú elemeitól?) Vagy a bevezetett információs technológiai eszközök mennyiségét, illetve azok rendelkezésre álló választékát kell mutatóként elfogadnunk? Vajon az IT költségekre kell koncentrálni, vagy az egy foóre jutó alkalmazásokra? Esetleg az a jobb megoldás, ha mindezt intézményi alapon vizsgáljuk? Hogyan lehet kvantifikálni annak a folyamatnak a jelentốségét, melynek során a mikroszámítógépes alkalmazások fejlődése messze maga mögött hagyja az úgynevezett mainframe rendszerekét? Továbbá, ha úgy döntünk, hogy az IT tényleges mibenlétére koncentrálunk, mit tekinthetünk releváns technológiának? A videoberendezések például vajon a személyi számítógépek elé sorolandók-e, és a hálózati rendszerek vajon megelớzik-e a robotikai alkalmazásokat? El lehet képzelni egy olyan időszakot, amelyben már kidolgozták az ,informatizálódás” bizonyos, széles körben elfogadott mérôszámait, ám még ekkor is fennmarad egy komoly kérdés: A fejlődési görbe mentén hol van az a fordulópont, amely elválasztja az információs társadalmat attól, amit csupán „fejlett ipari társadalomnak” szoktunk nevezni?

Ezt a második ellenvetést igen gyakran hangoztatják az információs társadalom technológiai meghatározásaival szemben. A bírálók tiltakoznak az olyan állítások ellen, hogy valamely adott területen a technológiákat elóször feltalálják, és azok csak ezt követốn hatnak a társadalomra, arra ösztönözve az embereket, hogy alkalmazkodjanak az újdonsághoz. A technológia e szerint a felfogás szerint elójogokat élvez minden mással szemben, és ebból adódnak az egész társadalomra kiterjesztett meghatározások: a gớzgép kora, az automobil kora, az atomkor és így tovább (Dickson 1974).

Legfóbb ellenvetésünk itt nem az, hogy ez a szemlélet, amelyik a technológiát tekinti a társadalmi dinamika fó tényezójének, óhatatlanul technológiai determinizmus és ennélfogva a változási folyamat túlzott leegyszerúsítése. Minden bizonnyal ez is igaz, de még fontosabb, hogy ez a felfogás teljesen leválasztja és külön kategóriába számúzi a technológiai innováció társadalmi, gazdasági és politikai dimenzióit. Ezek a technológia elsốrendú fontosságú birodalmából származnak, és annak alárendeltek, miközben úgy túnik, hogy maga a technológia önfenntartó, bár rányomja bélyegét a társadalom valamennyi aspektusára.

Ezzel a felfogással szemben kimutatható, hogy a technológia nem választható el ilyen módon a társadalom világától. Éppen ellenkezóleg, annak integráns alkotórésze. A kutatási és fejlesztési döntések például prioritásokat fejeznek ki, és ezekból az értékítéletekból kiindulva bizonyos típusú technológiák jönnek létre (a nyugati világban például a katonai programok a 20. század legnagyobb részében lényegesen több pénzügyi támogatást kaptak, mint az egészségügyiek, s ennek következtében - aligha meglepó módon - olyan szintú fegyverrendszerek jöttek létre, amelyek mellett a közönséges nátha kezelésében elért eredmények eltörpülnek). Számos vizsgálat kimutatta, hogy a 
technológiák mindig magukon viselik a társadalmi értékek lenyomatát, legyen szó akár a New York-i hidak megtervezéséról, amelyeknek a magasságát úgy határozták meg, hogy megakadályozzák a tömegközlekedési rendszerek behatolását bizonyos területekre, akár az olyan autók gyártásáról, amelyek megfelelnek a magántulajdon értékeinek, a család méretével kapcsolatos feltételezéseknek (tipikus esetben két felnôtt, két gyermek), a környezettel kapesolatos attitûdöknek (a nem megújítható energia tékozló és egyben környezetszennyezó felhasználása), bizonyos státusszimbólumoknak (a Porsche, a Mini, a Rover) és a közlekedés inkább egyéni, mintsem tömeges formáinak vagy pedig olyan házak felépítéséról, amelyek nem csupán lakóhelyek, hanem egyben az életmód, a presztízs és a hatalmi viszonyok vagy a különféle életstílusok iránti preferenciák kifejezôdései.

Erról a kérdésról igen kiterjedt irodalom született, nem kívánom azonban a mondandómat ad nauseam, a megcsömörlésig fejtegetni. Mindössze arra van szüikség, hogy az információs társadalom meghatározását illetôen leszögezzük ellenvetéseinket a technológia hiposztazálásával szemben. Hogyan lehet valami olyasmiról, amit a társadalomtól független jelenségnek tekintünk - esetünkben a technológiáról - elfogadható hitelességgel azt állítani, hogy az határozza meg a társadalmi világot?

\section{Gazdasági meghatározások}

A közgazdaságtannak van egy jól megalapozott ágazata, ami „az információ gazdaságtana" nevet viseli. Ezen belül - valójában e tudományág megalapítójaként - a néhai Fritz Machlup (1902-1983) szakmai munkásságának legnagyobb részét annak a célnak szentelte, hogy felmérje és értékelje az információs iparágak kiterjedését és növekedését. Machlup úttörő munkája, „A tudás termelése és elosztása az Egyesült Államokban” (The Production and Distribution of Knowledge of the United States, 1962) az információs társadalom gazdasági mércéinek kidolgozása terén alapmúnek számít.

Machlup megkísérelte statisztikai eszközökkel nyomon követni az információs iparágak fejlődését. Vizsgálataiban az alábbi öt nagyobb csoportot különböztette meg az ágazatban (összesen ötven alágazatra bontva):

a) oktatás (például iskolák, könyvtárak, fóiskolák);

b) kommunikációs médiumok (például rádió és televízió, reklámipar);

c) információs gépek (például számítógépes berendezések, hangszerek/zenei eszközök);

d) információs szolgáltatások (például jog, biztosítás, orvostudomány);

e) más információs tevékenységek (például kutatás és fejlesztés, nonprofit tevékenységek).

Ilyenfajta kategóriákkal dolgozva gazdasági értéket lehet hozzárendelni mindegyik csoporthoz, és nyomon lehet követni az egyes csoportok hozzájárulását a nemzeti össztermékhez (GNP). Ha az a trend érvényesül, hogy ezek a GNP növekvő hányadát állítják elô, akkor kijelenthetjük, hogy az idő függvényében kimutatható az információs gazdaság kialakulása. Pontosan ezt állította Machlup (1962) egy korai tanulmányában, amelyben úgy számította, hogy 1958-ban az Egyesült Államok GNP-jének 29 százaléka származott a tudás-iparágakból, ami abban az idốben figyelemre méltó mértékú bóvülést jelentett. 
A vezetéselméleti guru, Peter Drucker már az 1960-as években azt állította, hogy „a tudás vált a modern gazdaság alapjává”, ' mivel „az árucikkek gazdaságáról [áttértünk] a tudásgazdaságra" (Drucker 1969, 249, 247). Ma már közhelynek számít azt mondani, hogy olyan társadalommá fejlődtünk, melynek „megkülönböztetô jegye az, hogy [...] a gazdagság fớ létrehozói a tudás és a szervezés" (Karunaratne 1986, 52).

Az így felfogott információs gazdaság kialakulásának valószínúleg a legjobban ismert - és minden bizonnyal a legtöbbet idézett - elemzését Marc Porat (1977b) kilenc kötetben közzétett kutatási beszámolója nyújtja. Fritz Machlup az információs iparágak öt kategóriába sorolásakor a „tudástermelés” általános meghatározásait alkalmazta, tág értelemben ide sorolva mindazokat az ágazatokat, amelyek új információt termelnek, és azokat is, amelyek azt terjesztik. Porat nagyrészt Machlup megközelítését követte annyiban, hogy az USA gazdaságát az 1960-as évek végén leképezô számítógépes modelljének megtervezésekor a kormány statisztikai forrásaira támaszkodott, de a gazdaságot felosztotta „elsôdleges információs”, „másodlagos információs” és „nem információs" szektorokra. Ezt a hármas felosztású sémát azért alkalmazta, mert felismert egy gyöngeséget Machlup munkájában, aki nem vette számításba az olyan információs tevékenységeket, amelyek az eredeti vizsgálat szempontjából álcázottak lehettek, például azért, mert más iparágak belsố elemei voltak. Az „elsódleges információs szektorba” azokat az iparágakat sorolta, amelyek információikat hozzáférhetôvé teszik a meglevő piacokon vagy bárhol másutt, ahol azokhoz gazdasági érték rendelhető (például tömegközlési eszközök, oktatás, reklám, számítógépgyártás). Megpróbált továbbá azonosítani egy „másodlagos információs szektort” is, ami lehetôvé tette számára, hogy tipológiájába be tudjon illeszteni olyan fontos információs tevékenységeket is, mint például a kutatás és fejlesztés egy gyógyszeripari vállalaton belül, a kormányszerveknél belsô használatra szolgáló információk elókészítése vagy egy olajvállalat könyvtári forrásainak összeállítása.

Ilyen módon Porat képes volt megkülönböztetni kétféle információs szektort, majd ezeket ismét összevonta, elkülönítve belólük a gazdaság neminformációs elemeit, és végül - újra összesítve az országos gazdasági statisztikákat - arra a következtetésre jutott, hogy az USA nemzeti össztermékének 46 százalékát az információs szektor állítja elô. Ipso facto, ${ }^{*}$ „az Egyesült Államok ma információalapú gazdaság. Mint ilyen, egyúttal „információs társadalom, [ahol] a gazdasági tevékenység fơ színterei az információs áruk és szolgáltatások termelése, valamint [a másodlagos információs szektorba tartozó] állami és privát bürokráciák" (Porat 1978, 11).

Az információ gazdasági jelentôségének ilyen mennyiségi kifejezése igen figyelemre méltó teljesítmény. Nem meglepố tehát, hogy azok, akik meg vannak győzódve az információs társadalom kialakulásáról, az új korszakba vezetố utat kijelölő́ információs tevékenység emelkedô görbéjének kimutatására törekedve azóta is rutinszerúen fordulnak Machluphoz és különösen Porathoz mint szaktekintélyekhez.

1 „A közgazdaságtudományi szakirodalom az információ és a tudás szavakat hajlamos egymással felcserélhetô módon használni. Néha azonban a tudás kifejezést a különféle típusú információk aggregátumának jelölésére használják, ami lehetôvé teszi a közgazdászok számára, hogy a készletek (stock) és a forgalom (flow) kezeléséhez hasonló módon foglalkozzanak vele (Melody 1987, 314)."

* A tényból következően. (Lat.) - A ford. 
Az információs társadalom gazdaságtani megközelítésével kapcsolatban azonban vannak különbözó problémák is (Monk 1989, 39-63). Ezek egyike az, hogy a tények tárgyilagos bemutatására szolgáló súlyos statisztikai táblázatok mögött - abban a tekintetben, hogy milyen kategóriákat állítunk fel és mit számítunk bele az információs szektorba, illetve mit zárunk ki onnan - meghúzódik jókora mennyiségú rejtett, önkényes értelmezés és értékítélet.

Marc Porat számára például bizonyos nehézségeket okoz az olyan „kvázivállalatok" azonosítása, amelyek beágyazódnak valamely nem információs vállalkozásba. Ám abból a helyes feltételezésból kiindulva, hogy a kutatás és fejlesztés egy petrolkémiai vállalatnál is információs tevékenységet foglal magában, elfogadható-e, hogy ezt statisztikai célokból elkülönítsük a gyártási elemektól? Mindenesetre valószínúsíthetố, hogy a tevékenységek összemosódnak, mivel a $\mathrm{K}+\mathrm{F}$ szekció szorosan kötődik a termelési ágakhoz, és bármely számítási célból történő elkülönítése meghamisítja valódi szerepét. Általánosabban kifejezve: amikor Porat a „másodlagos információs szektort” vizsgálja, valójában minden iparágat feloszt információs és nem információs tartományokra. A „gondolkodás” és a „cselekvés” efféle megkülönböztetéseit azonban rendkívül nehéz elfogadni: Hová tegyük például a CNC-rendszerek múködtetését vagy a hierarchikus irányítási funkciókat, amelyek a termelés integráns elemei? Itt azzal az ellenvetéssel élhetünk, hogy Porat önkényesen végez felosztást az iparágakon belül, hogy felrajzolhassa a másodlagos információs szektort, szembeállítva a nem információs világgal.

Lehetséges, hogy az ilyen ellenvetések nem érvénytelenítik Machlup és Porat eredményeit, és fenntartásainkat nem is ezzel a céllal vázoltuk. Ezek csupán fel kívánják hívni a figyelmet arra, hogy a statisztikai táblázatokba óhatatlanul beszúrốdnek bizonyos értékítéletek, s ily módon alátámaszthatják az egészséges szkepticizmust az információs gazdaság kialakulásának efféle elgondolásaival szemben.

Egy második nehézség abban áll, hogy az összesített adatok elkerülhetetlenül homogenizálnak igen eltérố gazdasági tevékenységeket. Egészében tekintve lehet azt mondani, hogy a reklám és a televízió gazdasági értékének növekedése az információs társadalom eljövetelét jelzi, de az ember sürgôs szükségét érzi az információs tevékenységek között a minőségi alapú való különbségtételnek. Ha azt kérdezzük, hogy melyik gazdaságilag értékelt jellemzố fontosabb az információs társadalom kialakulása szempontjából, akkor azt kívánjuk a tudósoktól, hogy tegyenek különbséget például a stratégiai kutatóközpontoktól, a nagyvállalati agytrösztöktôl, a transznacionális bankházaktól, a 35 mm-es kamerák gyártóitól, a szoftvertervezóktól vagy a Saatchi és Saatchi cég reklámszövegíróitól származó információk között.

Az információs gazdaságtan múvelőinek lelkes igyekezete, hogy árcédulát akasszanak mindenre, azzal a szerencsétlen következménnyel jár, hogy elmulasztják megismertetni velünk az információs szektor igazán értékes dimenzióit. Machlup és Porat nem törekednek az információs társadalom kvantitatí és kvalitatí mutatóinak megkülönböztetésére, bár józan ésszel belátható, hogy a Sun négymillió eladott példányát aligha lehet nagyobb információs értékúnek tekinteni a Financial Times kétszázezer példányánál: az elóbbit jó okkal vélhetjük kevésbé informatívnak, noha a Sun példányainak eladásából származó bevételek gazdasági értéke kétségkívül nagyobb. Ehhez a megkülönböztetéshez még visszatérünk, mivel annak a lehetốségére utal, hogy olyan társadalom felé haladunk, amelyben az információs tevékenységnek - a GNP-hez való hozzá- 
járulásával mérve - nagy súlya van, de kevés következménnyel jár a gazdasági, társadalmi és politikai élet rugóira nézve.

Ezek a közgazdászok természetesen kizárólag az információs szektor kvantitatív mutatóinak kifejlesztésével foglalkoznak, s így az információ minőségi értékének kérdése számukra kevésbé fontos. Mindazonáltal itt még a saját mércéik szerint is problémák merülnek fel. Az egyik ilyen kérdés, amit már említettünk, a következó: A gazdasági növekedés mely pontjánál lépünk be az információs társadalomba? Amikor a GNP 50 százaléka származik információs tevékenységekból? Ez ésszerúen megválasztott pontnak túnik, amelynél - világos, kvantitatív terminusokkal kifejezve - az információ elkezd domináns szerepet játszani. Sajnos azonban (legalábbis az információs társadalom teoretikusai számára nem örvendetes módon) ettól a ponttól még bizonyos távolságra vagyunk. Machlup és Porat szorgalmas követóinek a tanulmányai segítségével bármikor megítélhetô, hogy vajon beköszöntött-e már az új korszak. Michael Rogers Rubin és Mary Taylor Huber (1986) nagyszabású kutatási program keretében felújították Machlup vizsgálatait, s ennek eredményeként arra a következtetésre jutottak, hogy az Egyesült Államokban a „tudásiparágak” hozzájárulása a GNP-hez 1958 és 1980 között 28,6 százalékról 34,3 százalékra emelkedett, ám eközben 1970 óta gyakorlatilag semmilyen változás nem történt, s ez „a teljes GNP más összetevốinek átlagos növekedési arányához képest rendkívül szerény növekedést jelent" (Rubin és Huber 1986, 3). Porat nagyhatású kutatásainak az említett szerzók által való megismétlése az 1970-es évekre szintén csekély bóvülést mutatott ki az információs szektorban, összehasonlítva a GNP más összetevóivel. Az effajta ökonometriai vizsgálatok aligha adják harsonaszóval hírül az információs társadalom beköszöntét.

\section{Foglalkoztatási meghatározások}

Az információs társadalom kialakulásának egyik kedvelt mutatója a foglalkoztatásban bekövetkezett változásokra helyezi a hangsúlyt. Egyszerúen szólva itt arról van szó, hogy akkor érkezünk el az információs társadalomba, amikor a foglalkozások, illetve a munkahelyek nagyobb része már az információs munka területére esik. Vagyis az információs társadalom akkor érkezik el, amikor az irodai dolgozók, a tanárok, a jogászok és a szórakoztatóipari dolgozók száma meghaladja a szénbányászok, acélmunkások, dokkmunkások és építốipari dolgozók számát.

A foglalkoztatási meghatározást gyakran kombinálják valamilyen gazdasági mutatóval. Marc Porat például úgy számította, hogy az 1960-as évek végén az USA munkaerejének valamivel kevesebb mint a felét az információs szektorban foglalkoztatták, s ez majdnem ötszáz százalékos növekedést jelentett egy évszázad során, mialatt a mezőgazdasági foglalkoztatás zuhanásszerúen csökkent, és az információs foglalkozások tömegesen gyarapodtak. A munkahelyek változó megoszlása felületesen szemlélve megfelelố mércének tû́nik. Végül is nyilvánvalónak látszik, hogy amikor a fizikai erớt és kézügyességet kívánó munka, például a szénbányászat vagy a föld megmúvelése visszaszorul, és helyébe egyre inkább különféle adatok és szövegek kezelése lép, mint például az oktatásban és a nagy, bürokratikus szervezetekben, akkor új típusú társadalomba lépünk be. Ma „csupán a munkaerố egyre zsugorodó kisebbsége fáradozik az 
üzemekben, és [...] a munkaerôpiacon ma az információs dolgozók játszanak domináns szerepet, akik annak a ténynek köszönhetôen keresik meg a kenyerüket, hogy birtokukban van a dolgok elvégzéséhez szükséges információ" (Stonier 1983, 7, 8).

Ezt a trendet számos beszámoló kiemeli. A Gazdasági Együttmúködési és Fejlesztési Szervezet (Organisation for Economic Co-operation and Development, OECD) két nagyhatású kiadványa $(1981,1986)$ például adatokat közölt az OECD valamennyi tagországából, amelyek „folyamatos növekedést jeleznek [...] elsôsorban az információ létrehozásával és kezelésével, valamint az ezt támogató infrastruktúra múködtetésével kapcsolatos foglalkozásokban” (1986). Másutt Marc Porat „az információs munkaerő megdöbbentô növekedési arányát” állapítja meg, kimutatva, hogy ez 1860 és 1980 között 18,7 évenként megduplázódott (Porat 1977a, 131), s ezáltal az Egyesült Államokat „az információs gazdaság küszöbére” juttatta (204).

A foglalkozások megoszlásában bekövetkezett váltás áll az információs társadalom legnagyobb hatású, Daniel Bell által kidolgozott elméletének középpontjában is. Bell a „fehérgalléros társadalom” (vagyis az információs munka) kialakulásában és az ipari munka hanyatlásában megnyilvánuló változásokat olyan mélyrehatónak látja, hogy ezek egyúttal az osztályalapú konfliktusok végét, a közösségi tudat gyarapodását és a nemek közötri egyenlóség megvalósulását is jelzi.

Bell elméletének vizsgálatával és kritikájával a következő fejezetben foglalkozunk, de itt is indokoltnak látszik megemlíteni néhány általános ellenvetést az információs társadalom foglalkoztatási mércéivel kapcsolatban. Fontos probléma merül fel a dolgozók bizonyos kategóriákba sorolásának metodológiáját illetôen. Itt ugyanis a végtermék - egy puszta statisztikai adat, amely pontosan megadja az információs dolgozók százalékos arányát - elrejti azokat a komplex eljárásokat, amelyek segítségével a kutatók kialakítják a saját kategóriáikat, és az embereket besorolják ezek egyikébe vagy másikába.

Marc Porat például kifejlesztett egy késóbb nagy hatásúvá vált tipológiát azoknak a foglalkozásoknak a meghatározására, amelyekben a dolgozók elsősorban az információ termelését, feldolgozását vagy elosztását végzik. Hármas felosztású rendszere több mint négyszáz olyan munkakörtípust vesz számításba, amelyek szerepelnek az USA népszámlálási és munkaügyi statisztikáiban (US Census and Bureau of Labour Statistics). Ezeket Porat a következóképpen magyarázza:

„Az elsó́ kategóriába azok a dolgozók tartoznak, akiknek az első́dleges tevékenysége
a tudás létrehozása és eladása. Ide tartoznak a tudósok, a feltalálók, a tanárok, a
könyvtárosok, az újságírók és a szerzók. A dolgozók második nagy oszálya azokat
foglalja magában, akik az információt összegyújtik és terjesztik. Ezek a dolgozók köz-
vetítik az információt a vállalatokon és a piacokon belül; felkutatják, koordinálják,
tervezik és feldolgozzák a piaci információkat. Közéjük tartoznak a menedzserek, a
titkárok és titkárnốk, az irodai dolgozók, a jogászok, a tốzsdeügynökök és a gépírók.
Az utolsó osztályba azok a dolgozók tartoznak, akik az elóbbi két tevékenységet tá-
mogató információs gépeket és technológiákat múködtetik. Ide sorolhatók a számí-
tógép-operátorok, a telefonszerelók és a televízió-múszerészek” (Porat 1978, 5-6).

Jonscher (1983) ezt a felosztást még tovább egyszerúsíti, mindössze két szektort különböztetve meg a gazdaságban: az elsố az információs szektor, ahol azok az emberek dolgoznak, akiknek az elsődleges funkciója az információ létrehozása, feldolgozása és 
kezelése; a második pedig a termelési szektor, ahol a dolgozók elsốsorban a fizikai javak előállítását, feldolgozását és kezelését végzik.

Ezek a megkülönböztetések ésszerúnek, pontosnak és empirikusan igazolhatónak tûnnek, de itt is vannak nehézségek. Közöttük nem csekély fontosságú, hogy „annak a pontos megállapítása, hogy ki információs dolgozó és ki nem az, kockázatos vállalkozás" (Porat 1978, 5). Valóban kockázatos, hiszen minden foglalkozás jelentós mértékú információfeldolgozást és kognitív tevékenységet foglal magában. Ezt Porat is elismeri, amikor a nem információs munkát az információs munkától annak alapján próbálja megkülönböztetni, hogy az egyes típusok milyen mértékben foglalják magukban az információt. Más szóval, a kategorizáláskor azt kell megítélni, hogy az egyes munkakörök milyen mértékben információsak, illetve nem azok. Az információs dolgozók puszta százalékos arányai elfedik azt a tényt, hogy a számok a kutatók becsléseinek eredményei (Porat 1977a, 3).

Egy vasúti váltó- és szemaforkezelőnek például komoly tudáskészlete kell legyen a vágányokról és a menetrendekról, a különféle dolgozók szerepeiról és rutinfeladatairól; kommunikálnia kell más váltó- és szemaforkezelókkel a vonal mentén, az állomások személyzetével és a mozdonyvezetókkel; mint a tenyerét, úgy kell ismernie saját fülkéjét és mások munkahelyeit; pontos és mindenre kiterjedó kimutatást kell vezetnie minden forgalomról, ami a területén zajlik; és a modern berendezések munkába állítása óta kevés fizikai erốre van szüksége a váltókarok és a jelzókarok átállításához. Ám a vasúti váltó- és szemaforkezelő kétségkívül az „ipari korszak” tipikus kétkezi dolgozója. Ezzel szemben az a személy, aki azért jön az irodába, hogy megjavítsa a fénymásoló gépet, esetleg csak azt a bizonyos berendezést ismeri, amelynek a javítására kiképezték, és igen keveset tud más termékekról, továbbá könnyen előfordulhat, hogy forróságban, piszkos és kényelmetlen körülmények között kell dolgoznia, és az is lehet, hogy a nehéz berendezések elmozdításához és a károsult alkatrészek kicseréléséhez komoly fizikai erốt kell kifejtenie. Ô azonban kétségtelenül az információs dolgozók kategóriájába fog kerülni, mivel az új korszak gépi berendezéseivel végzett munkája dr. Porat értelmezése szerint ennek felel meg.

A lényeg itt igen egyszerú: szkeptikusnak kell lennünk az olyan összesített adatokkal szemben, amelyek a kutatók azzal kapcsolatos nézeteinek az eredményeként adódnak, hogy az egyes foglalkozásokat hogyan kell a legmegfelelóbben kategorizálni. Tény, hogy a társadalomtudósok igen keveset tudnak az emberek munkájának részleteiról és bonyolultságáról; ritka kivételnek számítanak az olyan etnográfiai munkák, amelyek pontosan rögzítik a munkával töltött idő tényleges tartalmát (lásd Terkel 1977). És azok a kutatók, akik az információs és a nem információs munkát próbálják meg különböző címkékkel elkülöníteni egymástól, éppen olyan tájékozatlanok, mint társadalomtudós kollégáik fennmaradó része.

Ha gyanakvással élhetünk azokat a módokat illető́en, ahogyan a kutatók felfogják és meghatározzák az információs munkát, tudatában kell lennünk azoknak a túlegyszerúsítéseknek is, amelyek abból származhatnak, hogy igen változatos munkaköröket ugyanazokba a rekeszekbe gyömöszölnek be. Ian Miles helyesen állapítja meg az ilyen módszerekkel kapcsolatban, hogy „a különféle címszavak alá csoportosított munkakategóriák gyakran rendkívül heterogének" (Miles 1991, 917). Ha például figyelembe vesszük, hogy Marc Porat az elsố kategóriájába (az információ létrehozói közé) bezsúfol- 
ja az optikusokat, a könyvtári asszisztenseket, a zeneszerzóket, a papírkötésú könyvek szerzóit, az egyetemi professzorokat és a mérnököket, miközben a másodikban (az információ terjesztói között) együtt találhatók a legmagasabb szintú napilapok újságírói az utcai újságárusokkal, az OECD pedig információtermelóként együvé sorolja a fizikusokat, az árutôzsdei alkuszokat és az árverési kikiáltókat, akkor valóban kételyeink támadhatnak a foglalkozások ilyen összetételú csoportjainak mint a társadalmi változások kimutatására szolgáló eszközöknek az értékét illetốen. Mit kezdjünk továbbá azoknak a foglalkozásoknak a megnevezésével, amelyek igen sokrétú foglalkozási ágakat sorolnak ugyanabba a kategóriába? Könyvtáros például lehet az is, aki a nap legnagyobb részét kölcsönzésre kiadott könyvek átadásával, illetve a polcra való visszahelyezésével tölti, valamint az is, akinek az a napi rutinfeladata, hogy tudós kutatók számára adjon tanácsokat a legjobb információforrásokra nézve, amelyeket azok felhasználhatnak élenjáró kutatásaikban. Valóban értelmes dolog ilyen sokféleség együvé zsúfolása?

Végül az effajta homogenizálás egyik fontos következménye az is, hogy nem kerül sor a stratégiailag központi fontosságú információs foglalkozások meghatározására. A módszer nyújthatja azt a képet, hogy nagyobb mennyiségú információs munkavégzés történik, ám nem kínál semmiféle eszközt sem az információs munka legfontosabb dimenzióinak megkülönböztetésére. Az információs munka mennyiségi mutatóinak kidolgozására való törekvés elfedi azt a lehetôséget, hogy bizonyos típusú információs foglalkozások gyarapodásának különleges következményei lehetnek a társadalom életére nézve.

Rá kell mutatni, hogy az információs dolgozók megszámlálása valamely társadalomban nem mond semmit a hierarchiákról - és a hozzájuk társuló hatalmi és tekintélybeli különbségekról - ezek között az emberek között. Mondhatjuk azt például, hogy a döntố tényezố a számítástechnikai és távközlési mérnökök számának növekedése, hiszen ezek meghatározó befolyást gyakorolhatnak a technológiai innováció ütemére. Ehhez hasonló, sốt talán még nagyobb mértékủ gyarapodás ment végbe azoknak a szociális dolgozóknak a létszámában is, akik az idôs korú lakosság, a növekvô számú válások és a fiatal korú búnözés problémáival foglalkoznak, ám ennek aligha van sok köze az információs társadalomhoz, noha a szociális munkásokat kétségkívül információs dolgozóként kategorizálnák az információs technológia fejlesztéséról gondoskodó mérnökökkel együtt.

Elfogadhatóan lehetne érvelni továbbá amellett is, hogy az információs társadalom kialakulásában a döntố tényezố az elméleti tudás jelentốs térnyerése a gyakorlati készségekkel szemben. Ha azt állítjuk, hogy a mai társadalomban a fontos fejleményeket - akár a közgazdaságtan, akár a technológiai innováció terén - jól megalapozott elméletek (a gazdaságtudományban a keynesi, a monetarista stb. elméletek; a technológiában pedig a tudományos felismerések) indítják be, akkor meg kell különböztetnünk ennek az elméleti tudásnak a birtokosait azoktól, akik ugyan információs dolgozók, de csupán a teoretikusok által meghatározott gyakorlati feladatokat hajtják végre (például valamely gazdaságpolitika megvalósításával vagy egy laboratóriumi kísérlet elvégzésével).

Azt is mondhatjuk, hogy az információs társadalom leginkább meghatározó mutatója a nagyvállalati vezetók egy bizonyos „,belsó köre” (Useem 1985; Useem és Karabel 1986), ami teljesen különbözik elődeitól. Ebben olyan emberek találhatók, akiket kom- 
munikatív készségeik, elemzôképességeik, elôrelátásuk és stratégiák kidolgozására való képességeik ruháznak fel hatalommal, s ezeknek egyúttal kiváltságos oktatási hátterük, különféle klubtagsági és tanácskozótermi kapcsolatokból származó összeköttetéseik, továbbá kifinomult információs és kommunikációs technológiákhoz való hozzáférésük van. Mindezek együttesen különleges befolyást biztosítanak számukra a társadalmi, gazdasági és politikai ügyekben országos, sốt nemzetközi szinten is. Ezek is információs specialisták, de radikálisan különböznek azoktól a mindennapi taposómalomban tevékenykedó információs dolgozóktól, akiket a nyers adatok kvantitatív elemzéseiben velük egy kategóriába sorolnak.

$\mathrm{Az}$ információs dolgozók egyes csoportjai közötti kvalitatív megkülönböztetés szüikségességét talán jobban érthetôvé teszi, ha röviden kitérünk a társadalomtörténész Harold Perkin munkájára. „A professzionális társadalom kialakulása” (The Rise of Professional Society, 1990) címú könyvében Perkin azt állítja, hogy Nagy-Britannia története 1880 óta nagyrészt megírható azoknak a „professzionális” szakembereknek a csúcsra emelkedéseként, akiknek a hatalmát „az oktatás által létrehozott emberi tóke biztosítja [...] és a megfelelố képesítésekkel nem rendelkezók kirekesztése erốsíti meg” (2). Perkin arra a következtetésre jut, hogy ,a háború utáni társadalom fố szervezó elve" a bizonyítvánnyal igazolt szakértelem (406), és a valaha domináns csoportok (a földbirtokos arisztokrácia, a tókés vállalkozók és a munkásszervezetek) hatalmát a szakértók hatalma váltja fel, miközben azok elavult eszméit (a paternalista úriember, a tulajdon és a piac, illetve az együttmúködés és a szolidaritás ideáljait) felváltja a szolgálat, a szakmai képesítés és a hatékonyság professzionális ethosza.

Kétségtelen, hogy a magánszektorban múködő hivatásos szakemberek hevesen vitáznak az állam képviselóivel, de Perkin kitart amellett, hogy ez valójában csak a „professzionális társadalmon" belül folyó, egymást pusztító gyilkos küzdelem, amelyben a küzdő felek megegyeznek számos alapvetô feltételezésben (különösen a képzettségen alapuló szakértelem és az érdemek alapján szerzett jutalom elsóbbségében), és szigorúan kizárják a nem szakértóket a komoly részvételból.

Alvin Gouldnernek az „új osztályról” adott elemzése érdekesen egészíti ki Perkinét. Gouldner az alkalmazottaknak a 20. század során kialakult egyik új típusát olyan „új osztályként” határozza meg, amely „humán és múszaki értelmiségiekból tevốdik össze" (Gouldner 1979, 153). Ez az osztály, miközben részben a saját hasznát keresi, és gyakran alárendelódik a hatalmat birtokló csoportoknak, szintén veszélyeztetheti a gazdasági és politikai élet elfogadott vezetôinek a hatalmát. Az új osztály - e potenciális hatalma ellenére - maga is többféle módon van megosztva. A legfóbb ellentét az egyik oldalon a technokrata és konformista múszaki szakemberek, a másik oldalon pedig a kritikus és egyenlóségelvú humán értelmiségiek között nyilvánul meg. Harold Perkin szerint nagyrészt ez az ellentét jut kifejezésre a magánszektorban, illetve az állami szektorban dolgozó szakemberek között megnyilvánuló konfliktusokban is: a magánszektorban dolgozó könyvelók például többnyire konzervatívak, míg a humán értelmiségiek hajlamosak radikális nézeteket vallani.

A fố mondanivalóm itt az, hogy mind Gouldner, mind Perkin bizonyos változásokat állapít meg az információs munka világán belül, amelyek különösen fontos következményekkel járnak a társadalom egészére nézve. Gouldner szerint az „új osztály” új kifejezéskészlettel láthat el bennünket a társadalmi változások irányának megtárgyalá- 
sához az erról szóló vitákban, míg Perkin úgy látja, hogy a professzionális szakemberek új ideálokat teremtenek a társadalmi ügyek kezeléséhez.

Ha ezeknek a gondolkodóknak a munkáiban keressük az információs társadalom kialakulásának mutatóit, akkor bizonyos csoportok hozzájárulásának a minóségéhez jutunk el. Akár egyetértünk, akár nem ezeknek az értelmezéseknek bármelyikével, világossá kell válnia, hogy meg kell kérdôjeleznünk az információs társadalom olyan meghatározásait, amelyek az információs dolgozók puszta létszámán alapulnak. Az olyan gondolkodók szemében, mint Perkin és Gouldner, nem a mennyiségi változás a fố kérdés. Azoknak a csoportoknak a részaránya a lakosságban, amelyekre ók fektetik a hangsúlyt, valóban megnövekedett ugyan, de továbbra is csupán kisebbségeket - a Michael Useem-féle „belsố körben” törpe kisebbséget - alkotnak. Létszámuk az egyetemi végzettséget igénylő szakmák bóvüléséból adódóan jóval nagyobb lett ugyan, mint korábban volt, de sohasem lehet több a munkaerő 20-25 százalékánál.

\section{Térszemléletü meghatározások}

Az információs társadalom így meghatározott fogalma szintén a szociológiára és a közgazdaságtanra épít, ám középpontjában a geográfusok által a térre helyezett megkülönböztető hangsúly áll. A fő nyomaték az információs hálózatokra esik, amelyek összekötik a helyszíneket, s következésképpen drámai erejú hatást fejtenek ki az idô és a tér szervezódésére.

John Goddard (1992) az információs társadalomhoz vezetô átmenetben négy egymással összefüggó elemet határoz meg:

1. Az információ „kulcsfontosságú stratégiai erőforrásként” egyre inkább központi helyet foglal el a világgazdaság szervezôdését meghatározó színpadon.

A modern világ megkívánja a globálisan megosztott gyártási tevékenység koordinációját, a szuverén államok határain átívelő tervezést és a kontinenseket átfogó marketinget. E sokrétú tevékenységcsokor tengelyét az információ alkotja, amely ezért a mai világban kiemelt fontosságra tesz szert. Ebból az is következik, hogy az „információ-menedzsment” különleges szerephez jut, és ennek eredményeként tanúi lehetünk az információs foglalkozások gyors szaporodásának.

2. A számítógépes és kommunikációs technológiák biztosítják azt az infrastruktúrát, amely lehetôvé teszi az információ feldolgozását és terjesztését. Ezek a technológiák biztosítják továbbá, hogy az információkezelés történelmileg példátlan volumenúre duzzadjon, és nekik köszönhetóen megvalósíthatóvá válik a gyakorlatilag azonnali, „valós idejú” kereskedés, valamint a gazdasági, társadalmi és politikai ïgyek globális léptékben való monitorozása.

3. Különösen gyors növekedés ment végbe a gazdaságnak az „eladható információkkal" foglalkozó szektorában: ezen Goddard professzor azt érti, hogy különösen alá kell húzni az olyan szolgáltatások robbanásszerú növekedését, mint az új média (múholdas és kábeles músorközlés, videó) és az online adatbázisok, amelyek a témák egész sorában információt nyújtanak a részvénytốzsdei tranzakciókra vonatkozó hírektốl kezdve az árucikkek árain, a szabadalmi bejegyzéseken és a 
valutaárfolyamok ingadozásain keresztül a tudományos és technológiai folyóiratok absztraktjaiban foglalt új tudáselemekig.

Ezeket a fejleményeket kiegészíti a világ pénzügyi rendszerének radikális átszervezódése, melynek eredményeként megszúntek azok a hagyományos határok, amelyek valaha elválasztották egymástól a bankokat, a tôzsdéket, a pénzügyi szolgáltatásokat, a hitelügynökségeket és az ezekhez hasonló más intézményeket. A magas szintư pénzügyeknek ezen az ijesztố világán belül, amelyet kevesen értenek és még kevesebben látszanak képesnek ellenốrzésük alatt tartani, megdöbbentố nagyságú tốke cirkulál elektronikus formában.

4. A gazdaság fokozódó „informatizálódása” elősegíti a nemzeti és a regionális gazdaságok integrációját.

Az azonnali és hatékony adatfeldolgozás és információközvetítés révén a gazdaság valóban globálissá vált, és ezzel együtt csökkentek a térbeli távolságokból adódó korlátok. A vállalatok ma globális stratégiákat dolgozhatnak ki az áruk és a szolgáltatások létrehozásához, tárolásához és elosztásához, a pénzügyi érdekek folyamatosan érvényesülnek, azonnali reakcióra képesek, és behálózzák az egész bolygót. Azoknak a virtuóz módszereknek köszönhetốen, amelyekkel korunkban az információ kezelhetố és manipulálható, a földrajzi hely által meghatározott határok - és velük együtt a valaha az idő által kikényszerített korlátok is - egyre messzebbre tolódnak ki.

Mindezek a trendek együttvéve arra mutatnak, hogy központi szerephez jutnak az információs hálózatok, amelyek az egyes városokban, régiókban, országokban és kontinenseken levố helyszíneket összekötik egymással, valójában az egész világon.

Az elektromos hálózattal való analógiával, amire korábban az információs társadalom technológiai meghatározásainak tárgyalásakor hivatkoztunk, itt is gyakran találkozunk. Ahogy az elektromos hálózat átszövi az országok egészét, magában foglalva az egyéni háztartásokban beépített áramköröket is, ugyanúgy tételezhetố a ,behuzalozott társadalom" (wired society: Martin 1979), ahol országos, nemzetközi és globális szinten egyaránt múködik valamiféle gazdaságos „információellátási hálózat” (information ring main: Barron és Curnow 1978) minden egyes otthonra, üzletre vagy irodára kiterjedően. Ezen a folyamatosan bôvüló és egyre nagyobb kapacitású hálózaton keresztül mindannyian egyre szorosabb összeköttetésbe kerülünk egymással.

Számos szerző (például Hepworth 1989) az információs hálózatok technológiai alapjaira helyezi a hangsúlyt. Ebból fakadóan a kialakuló „hálózati társadalom” elemzései jelentős figyelmet szentelnek az ISDN-infrastruktúra fejlesztése terén elért eredményeknek, illetve az ezt akadályozó problémáknak (Dordick és tsai. 1981).

A „hálózati piactér” kialakulásával foglalkozó legtöbb gondolkodó azonban a technológia fontosságának elismerése mellett - miután leírnak egy-két tiszteletkört az IT fejlődésében központi helyet elfoglaló, ám általuk gyakran figyelmen kívül hagyott távközlési technológiák körül-azokra a módokra helyezik a hangsúlyt, ahogyan ezek a hálózatok még inkább kiemelik és megerôsítik az információáramlás jelentốségét (Castells 1989). A központi gondolat itt az „elektronikus országutak” mentén cirkuláló információ. Érdekes, hogy mindeddig senki sem tudta mennyiségileg meghatározni, hogy milyen sok információnak és milyen sebességgel kell áramlania ezek mentén az útvonalak 
mentén ahhoz, hogy létrejöjjön az információs társadalom. Valójában még senki sem tett közzé megbízható adatokat, amelyek átfogó képet nyújtanának az információforgalomról (vö. OECD, 1988). Vannak adataink a telefonvonalak sưrüségéról a lakosság lélekszámához viszonyítva, valamint a faxszolgáltatások bốvüléséról, és vannak statisztikáink a számítógépes rendszerek értékesítéséról és a távközlésben automatikusan továbbított üzenetekról stb., de továbbra is hiányzik a világos összesített kép e hálózatok méretéról, kapacitásáról és tényleges felhasználásairól.

Valamennyi megfigyelő tisztában van azonban az országhatárokat átlépó adatáramlások, a távközlési szolgáltatások és a számítógépek közötti kommunikáció nagyarányú növekedésével valamennyi szinten, az otthonoktól a transznacionális szervezetekig, az árutőzsdék és a nagyvállalati szektor összetevói közötti kapcsolatokig, a nemzetközi adatbázisokhoz való hozzáférésig és a telexen továbbított üzenetekig. Hasonlóképpen jelentốs mértékú figyelem kíséri a tömegközlési eszközök globális terjeszkedését, melynek nyilvánvaló és kiemelkedô példáját a múholdas televíziózás nyújtja, bár a megfelelő kép kialakításánál számításba kellene venni a hírek összegyúijtését és terjesztését végzố szolgáltatásokat is. Mint Geoff Mulgan megfogalmazta: „a hálózatok elképzelhetetlen mennyiségú üzenetet, párbeszédet, képet és utasítást közvetítenek" (Mulgan 1991, 1, kiemelés F. W.).

$\mathrm{Az}$ a kérdés, hogy a sokkal nagyobb mennyiségú és nagyobb sebességú információáramlás tényének megállapítása miért késztethet bennünket arra, hogy ebból kiindulva egy új típusú társadalom kialakulására gondoljunk, visszavisz bennünket a geográfusok részéról a tér szerepére fordított megkülönböztetett figyelemhez. Minden esemény bizonyos helyen és meghatározott időpontban megy végbe, ám a hely és az idő jellemző jegyei a hálózati társadalom létrejöttével átalakultak. Míg valaha a kereskedés csak fáradságos úton és lassan volt képes áthidalni a távolságokat, ma ez a számítógépesített kommunikációs technológiák segítségével gyakorlatilag azonnali hatállyal megtehető; míg valaha a nagyvállalatok tevékenységét lassan továbbított levelek útján kellett koordinálni, amelyeknek a megérkezésére napokig, sốt hetekig kellett várni, mialatt azok keresztülhaladtak az érdekelt feleket elválasztó távolságokon, ma ez azonnal megvalósítható a kifinomult telekommunikációs hálózatoknak és videokonferencia-berendezéseknek köszönhetően.

Röviden: a tér korlátai drámaian lecsökkentek, bár még semmi esetre sem szúntek meg teljesen. Ezzel egyidejúleg maga az idố is összezsugorodott, mivel a számítógépes kommunikáció és a telekommunikáció gyakorlatilag azonnalivá vált. Az idônek és a térnek ez az „összesúrúsödése” (timelspace compression), ahogyan Anthony Giddens nevezi, a vállalatok, a kormányzatok, só́t az egyének számára is mindeddig elérhetetlen választási lehetôségekkel szolgál.

Senki sem tagadhatja, hogy az információs hálózatok megléte a mai társadalmak fontos jellemzô vonása: a múholdak azonnali kommunikációt tesznek lehetôvé egész bolygónkon, az adatbázisok elérhetók Oxfordtól Los Angelesig és Tokiótól Párizsig, a faxkészülékek és az egymással összeköttetésben álló számítógéprendszerek a modern üzleti vállalkozások megszokott, mindennapi eszközei közé tartoznak.

Mégis feltehetjük a kérdést: A hálózatok jelenlétéból miért jutnak az elemzók arra a következtetésre, hogy egyes társadalmakat az információs gazdaságok kategóriájába soroljanak? Amikor feltesszük ezt a kérdést, ismét a definíciók pontatlanságának prob- 
lémájával találkozunk. Például mikor lesz valódi hálózat valamely hálózat? Amikor két személy telefonon beszél egymással, vagy pedig akkor, amikor számítógépes rendszerek óriási adathalmazokat továbbítanak egymás között valamely csomagkapcsolásos üzenetváltás során? Amikor egy irodaépületet teljes egészében „behuzaloznak”, vagy amikor az otthoni terminálok kommunikálhatnak a helyi bankokkal és üzletekkel? Az a kérdés, hogy ténylegesen mit nevezhetünk hálózatnak, komoly problémákat vet fel, és megválaszolása nehézségekbe ütközik, nem csupán abban a tekintetben, hogy a hálózatépítés különböző szintjeit hogyan különböztessük meg egymástól, de abban is, hogy miként határozzunk meg egy olyan pontot, amelynek elérésekor elmondhatjuk, hogy beléptünk a hálózati társadalomba vagy az információs társadalomba.

Felvetôdik továbbá az a kérdés is, hogy az információs társadalom meghatározásakor technológiai definíciót használjunk-e, vagyis a hálózatokat technológiai rendszerként definiáljuk-e, vagy pedig helyesebb lenne az információáramlásra koncentrálni, ami egyes szerzók szerint a jelenlegi korszak megkülönböztetố jegye. Ha az elóbbit választjuk, akkor mutatóként az ISDN-technológiák terjedését használhatnánk, ám kevés tudós nyújt bármi eligazítást is ahhoz, hogy ezt hogyan alkalmazzuk. Ha pedig az utóbbi mellett döntünk, akkor ésszerúen feltehető az a kérdés, hogy mennyivel nagyobb mennyiségú és menny̛ivel gyorsabb információáramlás elérésétól számítva beszélhetünk új típusú társadalomról, és miért.

Végül kimutathatjuk azt is, hogy információs hálózatok már igen hosszú ideje léteznek. A gazdasági, társadalmi és politikai élet - legalábbis a postai, majd a távirati és telefon-szolgáltatások beindulásától kezdve - jórészt elképzelhetetlen az ilyen információs hálózatok létrejötte nélkül. Ha ezt a hosszú ideje fennálló kapcsolatot és a hozzá adódó felgyorsult fejlődést adottnak vesszük, miért éppen az 1980-as években kezdenek el az elemzók információs társadalmakról beszélni?

\section{Kulturális meghatározások}

Az információs társadalom fogalmi meghatározásainak utolsó kategóriája talán a legkönnyebben értelmezhetó, ám a legkevésbé mérhetô. Mindennapi életünk gyakorlata alapján mindannyian tudatában vagyunk annak, hogy rendkívüli mértékben megnótt a társadalomban cirkuláló információk mennyisége. Egyszerúen sokkal több információval találkozunk, mint azelótt valaha is. A televízió már több mint 30 éve elterjedt Nagy-Britanniában, ma azonban a músorokat már 24 órán keresztül közvetítik, és az emberek nézhetik a televíziót reggeltól kezdve másnap hajnalig. Egyetlen, közvetítési szünetekkel múködő csatornától mára már négy músorközlő csatornáig jutottunk el (és hamarosan beindul egy ötödik is). És ezenkívül már rendelkezésünkre állnak a videotechnológiák, a kábeles és múholdas csatornák, sốt az olyan számítógépes információs csatornák is, mint például a teletext. Ma helyi, országos és nemzetközi szinten egyaránt sokkal több rádiómúsort készítenek, mint akár csak egy évtizeddel ezelő́tt. Továbbá a rádiókészülékek már nemcsak a nappali szobákban múködnek, hanem mindenütt, az otthonainkban, az autókban, az irodákban és - a walkman megjelenése óta valóban mindenütt. A filmek hosszú ideig fontos részét alkották az emberek információs környezetének, ám ma a mozik tényleges látogatottsága lényegesen csökkent. Ma- 
guk a filmek viszont ma sokkal jobban elterjedtek, mint valaha: még mindig elérhetók a mozikban is, de emellett sugározzák óket a televíziós csatornák, egyszerúen hozzájuk juthatunk a videokölcsönzókboól, és olcsón megvásárolhatók az áruházláncok polcairól. Ha bármelyik utcán végigsétálunk, szinte lehetetlen nem észrevenni a különféle hirdetéseket, a plakátokat és az üzletek kirakatait. Látogassunk el bármely vasúti vagy autóbusz-állomásra, és feltétlenül szemünkbe kell ötlenie a papírkötésú könyvek és olcsó magazinok mindenütt elérhető kínálatának, a klasszikusoktól a középszerú és olcsó kiadványokon és az öngyógyításon át a ponyvairodalomig mindeddig példátlan választékban és mennyiségben. Ezenkívül a rádió, a magnetofonkazetták és kompaktlemezek egyre több és több zenét, költészetet, drámát, humort és oktatási anyagot közvetítenek a nagyközönséghez. Az újságok szintén mindenütt elérhetók, és jó néhány új kiadvány kerül a postaládánkba. Naponta kapjuk a nem kívánt, reklámtartalmú üzeneteket...

Mindez azt a tényt bizonyítja, hogy médiával terhelt társadalomban élünk, ám világunkba az információs jegyek még mélyebbre behatoltak, mint amennyire azt a televíziós, rádiós és más médiarendszerek rövid felsorolása jelezheti. Az ilyenfajta számbavétel azt mutatja, hogy új médiumok vesznek körül bennünket, olyan üzenetekkel elárasztva mindnyájunkat, amelyekre tetszésünk szerint válaszolhatunk vagy nem válaszolhatunk. Valójában azonban az információs környezet még ennél is sokkal intimebbé, még inkább hozzánk tartozóvá, résziinkké vált. Gondoljunk csak például a telefonra, amely ma az emberek túlnyomó többségének rendelkezésére áll. Teljes mértékben nélkülözhetetlen mindennapi életünk megszervezéséhez, ha például bébiszitterre vagy villanyszerelőre van szükségünk, vagy csak meg akarjuk tudni, hogy a nagypapa jól van-e... Ilyen információs technológiák nélkül csak a legnagyobb nehézségek árán tudnánk élni (bár a kommunikációs berendezéseket nélkülöző kisebbségnek még ma is ez a sorsa). Vegyük figyelembe továbbá, hogy gyakorlatilag minden családban van legalább egy fényképezőgép, amelyet a fontos események (házasságok, születésnapok, ünnepek) megörökítésére használnak. Egyre többünknek van videokamerája is, amellyel mindezeket még kézzelfoghatóbban tudjuk rögzíteni. Lépjünk be ma bármelyik otthonba, és a falakon, az albumokban és a tv-készüléken azoknak a közvetett ábrázolásaival találkozunk, akik ott élnek, és akik fontosak az ố számukra, de nincsenek jelen. Ezek az imázsok nem csupán a családtagoknak és barátaiknak a képei: amit megjelenítenek, az valójában ezeknek az embereknek az életrajza és identitása.

Figyelembe vehetjük továbbá ruházatunk, hajviseletünk és arcunk információs dimenzióit is, azokat a módokat, ahogyan ma kidolgozzuk a saját imázsunkat (az emberek testük alakjától a beszédükig intenzíven figyelnek azokra az üzenetekre, amelyeket ezek révén kifejezésre juttatnak, és ahogyan önmagukról vélekednek bizonyos öltözetekben, valamilyen sajátságos frizurával stb.). Néhány pillanatnyi túnődés a divat rejtelmeiról, azokról a bonyolult módokról, ahogyan megtervezzük önmagunk mindennapi bemutatását, ráébreszti az embert arra, hogy a társadalmi érintkezésnek ma jóval nagyobb információtartalma van, mint korábban.

Az otthonok is a történelemben egyedülálló mértékig információval terheltek. A bútor, a berendezés és a dekoráció - a G-plan stílus, a Laura Ashley szófa, a William Morris tapéta... és ezek közül néhánynak vagy mindegyiknek a keveredése, ízléstôl és pénztárcától függóen - mind-mind eszméket és ideálokat fejez ki. Az otthonok az ipari forra- 
dalom napjai óta minden bizonnyal mindig is jelezték az életmódot: gondoljunk csak például a „tisztes” dolgozó osztály stílusára a késố viktoriánus korszakban, vagy az értelmiségi középosztály megkülönböztetố stílusjegyeire a két háború között. A leginkább figyelemreméltó azonban az utóbbi évtizedekben a robbanásszerúen növekedố változatosság, és ennek elérhetôsége a nagy tömegek számára. Megdöbbentố perspektíva nyílt meg a közlés és a jelentésadás elốtt.

Az információnak az otthonunk, a hálószobánk és a testünk legintimebb birodalmába való behatolását kiegészíti azoknak az intézményeknek a növekedése, amelyeknek az a feladatuk, hogy mindennapi életünket felruházzák szimbolikus jelentésekkel. Gondolhatunk itt a globális reklámüzletre, a kiadói birodalmakra, a divatiparra vagy az egész világot átfogó médiaügynökségekre, amelyek behozzák otthonainkba a saját életmódunk reflexióit és más életstílusok képeit, olyan alternatív célokkal látva el bennünket, amelyeket magunkévá tehetünk, elutasíthatunk vagy újraértelmezhetünk, és mindeközben bővítik szimbolikus környezetünk szótárát.

Az olvasók észre fogják venni és tudomásul veszik a modern élet információs tartalmának ezt a rendkívüli gazdagodását. A kortárs kultúrát kifejezetten erôsebben terheli információ, mint bármelyik elődjét. Médiumokkal átitatott környezetben élünk, ami azt jelenti, hogy az élet lényegében szimbólumok, önmagunkról és másokról szóló üzenetek cseréje és befogadása - vagy az erre irányuló próbálkozások, illetve a befogadás elutasítása - körül forog. Ennek a jelentésrobbanásnak a felismerése az, amiból számos szerzó arra következtet, hogy beléptünk az információs társadalomba. Ezek az elemzók ritkán kísérelik meg ezt a fejlődést mennyiségi terminusokkal jelezni, inkább abból a „nyilvánvaló” tapasztalatból indulnak ki, hogy a jelek tengerében élünk, jelekkel jóval inkább telített környezetben, mint bármely elóbbi korban.

Paradox módon talán éppen ez az információrobbanás az, ami egyes szerzóket arra késztet, hogy beharangozzák ,a jel halálát”. Jelekkel bombáztatva mindenfelól, s közben önmagunkat is jelekkel „megtervezve” képtelenek vagyunk megszabadulni a jelektól, akárhová is megyünk - s ez különös módon azzal az eredménnyel jár, amit a jelentés összeomlásának nevezhetünk. Ahogy Jean Baudrillard megfogalmazza: „egyre több és több információ van, és egyre kevesebb jelentés" (1983a, 95). E felfogás szerint a jeleknek valaha referenciafunkciójuk volt (a ruhák például valamely adott státust, a politikai nyilatkozatok bizonyos filozófiát jeleztek, a tévéhírek pedig azt, ami valóban „történt”). A mai „posztmodern” korban azonban a jelek olyan elrémítő hálójába gabalyodunk bele, hogy azok már nem is ötlenek a szemünkbe. A jelek olyan sok irányból érkeznek, olyan sokfélék, gyorsan változók és ellentmondásosak, hogy jelentéshordozó erejük megfakul, elhomályosodik. Ugyanakkor a közönség kreatív, öntudatos és reflexióra kész, olyannyira, hogy minden jelet kétkedéssel és kritikusan fürkésző szemmel fogad, s ennélfogva könnyedén átalakítja, újraértelmezi vagy elválasztja óket eredetileg szándékolt jelentésüktól.

Ahogy az emberek közvetlen tapasztalatokból származó tudáskészlete csökken, nyilvánvalóvá válik, hogy a jelek többé nem egyenes és megbízható képviselói valaminek vagy valakinek. Az a felfogás, hogy a jelek valamilyen önmagukon kívüli „valóságot” képviselnek, elveszíti hitelességét. A jelek inkább önmagukra utalnak, és mint $s \approx i$ mulációk csupán magukban állnak. Ismét Baudrillard terminológiájával élve: a jelek afféle hiperrealitást képviselnek. 
Az emberek elég könnyen elfogadják ezt a helyzetet: kinevetik a pozôrt, aki valami hatáskeltés céljából öltözködik, de tudatában vannak, hogy egyébként is minden mesterkedés; szkeptikusok azokkal a politikusokkal szemben, akik a médiát és saját imázsukat ügyes PR útján „menedzselik”, de elfogadják, hogy az egész ügy végül is csupán információkezelés és manipuláció dolga. Ebból az a következtetés vonható le, hogy az emberek nem igényelnek többé semmiféle valódi jeleket, mivel felismerik, hogy nincsenek többé igaz valóságok. Ilyen értelemben beléptünk a puszta „látványosságok" korába, amelyben az emberek felismerik a nekik küldött jelek mesterséges voltát („,ez csak John Major a legutóbbi fotózása alkalmából”, „ez a hírgyárból származik”, „Jack a kemény fickót játssza”), és amelyben tudomásul veszik azoknak a jeleknek a nem autentikus voltát is, amelyeket felhasználnak önmaguk felépítésére (,majd megfelelő arcot vágok”; „itt az aggódó szüloó szerepét játszottam”).

Végeredményben a jelek elveszítik jelentésüket, és az emberek mindabból, amivel találkoznak, egyszerúen azt fogadják el, ami a kedvükre van (rendszerint az eredetileg szándékozottól igen eltéró jelentéssel). Ezután pedig összerakva a jeleket otthonaik, munkájuk és önmaguk számára boldogan lubickolnak azok mesterségességében, „játékosan” összekeverve különféle imázsokat anélkül, hogy bármilyen meghatározott jelentés közvetítésére törekednének - ehelyett inkább például a punk és az 1950-es évekre jellemzớ Marilyn Monroe-stílus kombinációjának paródiájában lelve örömet. Az ilyen információs társadalomban tehát „olyan jelentések halmazával vagyunk elborítva, amelyeket közvetítenek hozzánk, de nincs értelmük" (Poster 1990, 63).

Az így felfogott információs társadalom tapasztalati úton elég könnyen felismerhetố, egy új társadalom meghatározásaként azonban még sokkal szeszélyesebb és kiszámíthatatlanabb, mint az előző́ekben vizsgált bármelyik, ettôl eltérố nézôpontból kialakított társadalomkép. Mivel hiányoznak azok a kritériumok, amelyeket felhasználhatnánk az utóbbi évek szignifikációs dömpingjének kvantitatív módszerekkel való mérésére, nehéz megállapítani, hogy a posztmodernizmus olyan tanítványai, mint például Marc Poster (1990), milyen alapon tudják a jelent mint újszerú „,információs móddal" jellemezhetô kort leírni. Honnan tudhatnánk, ha nem a saját belátásunk alapján, hogy ma több szimbolikus kölcsönhatás megy végbe, mint azelốtt? Ha pedig nem csupán az eltérések mértékéból ítélünk, milyen alapon különböztethetjük meg ezt a társadalmat mondjuk az 1920-as évekétól? Mint a 8. fejezetben látni fogjuk, azok, akik a „posztmodern állapotról” értekeznek, érdekes dolgokat tudnak mondani a kortárs kultúra jellegéról, de az információs társadalom világos meghatározásával feltúnően adósok maradnak.

\section{Minôség és mennyiség}

Az információs társadalom ilyen sokféle meghatározásának áttekintéséból annyi feltétlenül világossá válik, hogy ezek a definíciók vagy nem eléggé kidolgozottak, vagy pontatlanok, vagy pedig mindkét bírálattal illethetók. Akármelyiket is vesszük szemïgyre a technológiai, gazdasági, foglalkoztatási, térszemléletú vagy kulturális felfogások közül, erôsen problematikus fogalmakat kapunk arra nézve, hogy mi hozza létre az információs társadalmat, és azt mi különbözteti meg a többitól. 
Fontos, hogy tudatában legyünk ezeknek a nehézségeknek. Noha heurisztikai eszközként az információs társadalom kifejezésnek van bizonyos értéke a mai világ jellemzố vonásainak feltárásában, ez a fogalom túlságosan pontatlan ahhoz, hogy meghatározó terminusként elfogadható legyen. Ebból kifolyólag e könyvben mindvégig gyanakvással kezelem az információs társadalom forgatókönyveit, és szkeptikus maradok azzal a nézettel szemben, hogy korunk fó megkülönböztetô jegyévé az információ vált, bár alkalmanként használni fogom az információs társadalom fogalmát, és következetesen elismerem, hogy korunkban az információ kritikus szerepet játszik.

Egyelơre azonban néhány további nehézséget kívánok megemlíteni az információs társadalom nyelvezetével kapcsolatban. Az első probléma azokkal a mennyiségi, illetve minóségi mércékkel kapcsolatban merül fel, amelyekre már utaltam. Korábban fóleg azzal foglalkoztam, hogy a kvantitatív megközelítések nem tudják megkülönböztetni a stratégiai fontosságú információs tevékenységeket a rutinszerú és alacsony szintû́ információkezeléstôl, és ez a homogenizálás félrevezetô. Itt ismét fel kívánom vetni a minôség és a mennyiség témáját, azzal a kérdéssel összefüggésben, hogy az információs társadalom kialakulása vajon valóban törést jelent-e az elốzố társadalomfajtákhoz képest.

Az információs társadalom legtöbb meghatározása kvantitatív mércét nyújt (a fehér galléros dolgozók száma, az információra fordított GNP százalékos aránya stb.), és azt feltételezi, hogy valamely meghatározatlan pontnál belépünk az információs társadalomba, ahol ez a mutató domináns szerephez jut. Nem nyújtanak azonban világos alapot annak megítéléséhez, hogy miért nevezzük új típusú társadalomnak azt, amelyben mindössze annak vagyunk tanúi, hogy nagyobb mennyiségú információ áramlik, illetve tárolódik. Ha csupán arról van szó, hogy sokkal több információ van forgalomban, akkor nehéz megérteni, miért állíthatja bárki, hogy valami radikálisan új áll elöttünk. Erre találóan mutat rá Anthony Giddens, amikor megállapítja, hogy minden társadalom - mihelyt nemzetállammá válik - információs társadalom annyiban, hogy múködésében alapvetô jelentôségúvé válik a lakosságra és a rendelkezésre álló forrásokra vonatkozó információk összegyújtése, tárolása és ellenórzése (Giddens 1985, 178). E tengely mentén a jelenlegi korszakot például a 19. századi Angliától mindössze az különbözteti meg, hogy ma sokkal nagyobb információmennyiségek felhalmozása, feldolgozása és látszólagos feldolgozása vagy ignorálása történik.

Ezzel szemben azonban leírható egy olyan újfajta társadalom, amelyben lehetséges a minőségileg más szintú és más funkciójú információk megtalálása. Ehhez még annak a felfedezésére sincs szükség, hogy a munkaerố többsége információs foglalkozásokban dolgozik, vagy hogy a gazdaság az információs tevékenységból bizonyos pénzösszegeket képes generálni. Elméletileg lehetséges például elképzelni egy olyan információs társadalmat, ahol az információs szakértók csekély kisebbsége tartja kezében a hatalmat. Kurt Vonnegut sok évvel ezelótt megalkotta ezt a képet a „Gépzongora" (Player Piano) címú regényében, és ez a látomás képezi az anyagát a tudományos-fantasztikus irodalom egyik jelentős almúfajának. Elég, ha csak H. G. Wells írásaira vetünk egy pillantást, hogy felfogjunk egy olyan társadalmat, amelyben egy „tudáselit" van hatalmon, és a többséget, ami a gazdasági követelmények teljesítéséhez fölöslegessé válik, semmittevésre és munkanélküliségre kárhoztatják. Mennyiségi mércékkel, például a foglalkoztatási minták alakulásával mérve ez nem felelne meg az 
információs társadalom státusának, de az információ és a tudás által a hatalmi struktúrában és a társadalmi változásokban játszott meghatározó szerep miatt kísértést éreznénk arra, hogy így nevezzük.

A kényes pont itt az, hogy a mennyiségi változás - egyszerúen a több információ önmagában nem jelezheti az elszakadást valamely elôzố rendszertól, miközben legalábbis elméletileg lehetséges, hogy csekély, de döntô minốségi változásokat a rendszerben bekövetkezett törés jelzóiként fogjunk fel. Ám különösen furcsa, hogy azok közül, akik az információs társadalmat a társadalom új típusának tekintik, oly sokan abból a feltételezésból indulnak ki, hogy ezt a kvalitatív változást egyszerűen meg lehet határozni annak a kiszámításával, hogy mennyi információ áramlása megy végbe, hány ember dolgozik az információs foglalkozásokban és így tovább. Itt azzal a feltételezéssel van dolgunk, hogy a mennyiségi növekedés - meghatározatlan módokon - minôségi változássá alakul át a társadalmi rendszerben.

Figyelemreméltó, hogy azok a tudósok (például Herbert Schiller és David Harvey), akik a jelen és a múlt közötti folyamatosságot hangsúlyozzák, miközben elismerik az információ egyre inkább központi jelentôségúvé váló szerepét, mindenekelótt szükségesnek érzik, hogy különbséget tegyenek az információ különféle kategóriái között és azok között a célok között is, amelyekre azokat felhasználják. Más szóval azok, akik szerint az „informacionalizált” társadalom világa nem különbözik radikálisan a múlttól, mindenáron arra törekednek, hogy a különféle információkat kvalitatív alapon különböztessék meg. Megvizsgálják például, hogy az információ elérhetốségét hogyan befolyásolta a piaci kritériumok alkalmazása, és azt bizonygatják, hogy a társadalom gazdagabb szektorai különösen kiváló minôségú információhoz jutnak hozzá, ami megerősíti hatalmukat és privilégiumaikat. Ám az informatizálódásnak ezt a minốségi dimenzióját annak érdekében hangsúlyozzák, hogy rámutassanak a társadalmi-gazdasági rendszer folyamatosságára. És viszont: azok, akik szerint az információs társadalom a korábbitól radikálisan eltérố rendszer, a mélyre ható minôségi változások kimutatása érdekében nagyon gyakran kvantitatív mutatókhoz folyamodnak.

Theodore Roszak (1986) az információs társadalom tárgyában közzétett kritikájában érdekes megvilágításba helyezi ezt a paradoxont. Vizsgálataiban hangsúlyozza az információ különféle szintjei közötti minốségi különbségtételt, és az információ kiterjesztett fogalomkörébe sorolja azt is, hogy mindennapi tevékenységeink során megkülönböztetjük egymástól az adatnak, tudásnak, tapasztalatnak, illetve bölcsességnek nevezett jelenségeket. Ezek minden bizonnyal maguk is csuszamlós terminusok, de alapvetően hozzátartoznak mindennapi életünkhöz. Roszak felfogásában a jelenlegi „,információkultusz" fó funkciója az, hogy lerombolja az ilyen fajta kvalitatív megkülönböztetéseket, amelyek a valódi életból adódnak. Ezt annak makacs hangoztatásával valósítja meg, hogy az információ tisztán mennyiségi jellegú dolog és statisztikailag mérhetô. Ám az információs iparágak gazdasági értékének, az információs tevékenységekre költött GNP arányának vagy a nemzeti jövedelem „megtermeléséból” az információs foglalkozásokra jutó százalékos hányadnak a kiszámításakor nem veszik figyelembe a tárgy kvalitatív dimenzióit (vagyis azt, hogy az információ hasznos-e vagy haszontalan, illetve igaz-e vagy hamis). „Az információ teoretikusainak a szemében nem számít, hogy tényt vagy ítéletet, sekélyes közhelyet, mély tanítást, nagyszerú igazságot vagy valamilyen undok trágárságot továbbítunk" (Roszak 1986, 14). Az információ homogenizálásával és meg- 
számlálásra alkalmassá tételével félresöprik ezeket a kvalitatív kérdéseket: „az információ a kommunikált üzenetek tisztán mennyiségi mértékévé válik" (uo. 11).

Roszak számára az a megdöbbentô, hogy az információ ilyen kvantitatív mérésével együtt járhat az a meggyớzớdés, hogy a több információ mélyrehatóan átalakítja a társadalmi életet. Az információs társadalom teoretikusai - miután félelmetes és lehengerlő információs statisztikákat produkálnak az információs tevékenységekról, elhomályosítva az olyanfajta minőségi megkülönböztetéseket, amelyeket mindannyian teszünk mindennapi életünkben - azt állítják, hogy ezek a trendek minôségileg meg fogják változtatni egész életünket.

Roszak erốteljesen vitatja az információ ilyenfajta felfogását. A számítógépek térhódításáról, az új technológiák adatfeldolgozó kapacitásáról és a digitalizált hálózatok kialakulásáról szóló statisztikai kimutatásokról készített további statisztikai elemzések „étrendjének” óriási kínálata alapján az emberek készségesen elhiszik, hogy az információ a társadalmi rendszer alapvetố fenntartó tápláléka. Olyan sok van ebból a táplálékból, hogy az ember valóban kísértést érez, hogy egyetértsen az információs társadalomnak azokkal a teoretikusaival, akik makacsul állítják, hogy teljesen újfajta rendszerbe léptünk be. Ám ezzel a „Nagyobb mennyiségú információval a társadalom új minốsége felé!” mantrával szemben Theodore Roszak ragaszkodik ahhoz, hogy a „fó eszmék" (masterideas, 91), amelyekre civilizációnk épül, egyáltalán nem az információn alapulnak. Az olyan elvek, mint például a „minden ember egyenlőnek van teremtve”, „a hazáért jóban-rosszban”, „élni és élni hagyni”, „mindannyian Isten gyermekei vagyunk” és „tedd másokkal azt, amit magad szeretnél kapni”, társadalmunk központi eszméi - és mindegyik megelózi az információt.

Fontos rámutatni, hogy Roszak nem azt állítja, hogy ezek és más „fő eszmék” szükségképpen helyesek (sok általánosan elterjedt nézet - például „minden zsidó gazdag”, „minden nố engedelmes”, „a feketék született atléták” - valójában kifejezetten káros). Azt hangsúlyozza, hogy az eszmék és az ezekból fakadó, szükségszerúen kvalitatív állásfoglalások elsóbbséget élveznek az információ kvantitatív megközelítéseivel szemben. És különösen határozottan tiltakozik az ellen, hogy az információs társadalom teoretikusai az ellenkezójére fordítsák ezt a helyzetet, miközben becsempészik azt a (téves) gondolatot, hogy a több információ alapvetóen átalakítja a társadalmat, amelyben élünk.

\section{Mi az információ?}

Abból kiindulva, ahogyan Roszak elutasítja a statisztikai mérószámokat, eljuthatunk az információs társadalom különféle megközelítéseinek talán a legfontosabb jellemzố vonásáig, mégpedig annak köszönhetốen, hogy Roszak erốteljesen érvel a minóségi értékítéleteknek az információval kapcsolatos diskurzusba való visszahozása mellett. Ilyen kérdéseket tesz fel: Több információ vajon szükségképpen jobban informált állampolgárokká tesz-e bennünket? Több információ elérhetôvé válásával tájékozottabbá válunk? Milyenfajta információk létrehozásáról és tárolásáról beszélünk, és milyen értéke van annak az egész társadalom szempontjából? Milyenfajta információs foglalkozások szaporodnak, miért és mi végre? 
Itt nem másról van szó, mint arról, hogy ragaszkodunk az információ jelentésének a vizsgálatához. Ez pedig minden bizonnyal hozzátartozik az információ kifejezés józan ésszel belátható értelmezéséhez. Végül is az információ legelsô meghatározása, ami az ember eszébe ötlik, a szemantikai definíció: az információnak jelentése van; tárgya van; valamire vagy valakire vonatkozó értesülést vagy utasítást tartalmaz.

Ha az információ így értelmezett fogalmát megkísérelnénk alkalmazni az információs társadalom meghatározására, ebból az következne, hogy az információnak ezeket a jellemzó vonásait kellene tárgyalnunk. Azt mondanánk, hogy az ilyenfajta kérdésekre, ezekre és ezekre a területekre, illetve gazdasági folyamatokra vonatkozó információ az, amely létrehozza az új kort. Azonban az információnak éppen az ilyen, köznapi józan ésszel felfogható meghatározásai azok, amelyektól az információs társadalom teoretikusai meg akarnak szabadulni: valójában azt nem hajlandók belátni, hogy az információnak szemantikai tartalma van.

Az információs társadalom meghatározásai, amelyeket áttekintettünk, az információt nem a jelentésteli oldaláról fogják fel, vagyis az információ szaporodásának kvantitatív bizonyítékait keresve a gondolkodók egész sora Claude Shannon és Warren Weaver (1964) klasszikus információelméletének szellemében fogja fel az információt. Ez az elmélet az információ pontos meghatározását adja, amely élesen eltér a mindennapi beszédben használatos szemantikai fogalomtól. Az elmélet szerint az információ olyan mennyiség, amely bitekben mérhetố, és bizonyos szimbólumok elôfordulási valószínúségének kifejezésével határozható meg. Ez a definíció a híradástechnikai mérnökök szakmai gyakorlatából származtatható, és azok számára hasznos, akik olyan szimbólumok tárolásával és átvitelével foglalkoznak, amelyek - minimális mutatóként - bizonyos áramkörök bekapcsolt vagy kikapcsolt (igen/nem vagy 0/1) állapotaival indexelhetốk. Ez a megközelítés lehetôvé teszi, hogy az információ egyébként igen sok vesződséget okozó fogalma matematikailag kezelhetôvé váljék, ezért azonban azt az árat fizetjük, hogy a jelentés ugyanennyire nyugtalanító - ám döntó fontosságú - kérdéséról s ezzel együtt az információ minőségének a jelentéstốl elválaszthatatlan kérdéséról is le kell mondani. A mindennapi szinten, amikor információt adunk-kapunk vagy cserélünk, elsősorban annak a jelentése és az értéke érdekel bennünket: vajon jelentôs, pontos, abszurd, érdekes, megfelelő vagy hasznos-e az számunkra. Az információelmélet számára azonban, amelyre az információrobbanás olyan sokféle mércéje támaszkodik, ezek a dimenziók irrelevánsak. Itt az információ meghatározása a tartalmától függetlenül történik, éppen olyan fizikai elemnek tekintve azt, mint amilyen az energia vagy az anyag. Ahogy az információs társadalom egyik leghívebb apostola megfogalmazza:

„Az információ létezik. Nem szükséges észlelni ahhoz, hogy létezzen. Nem szükséges megérteni ahhoz, hogy létezzen. Értelmezéséhez nines szükség intelligenciára. Létczéséhez nincs szüksége jelentésre. Létezik" (Stonier 1990, 21).

E szerint a felfogás szerint két olyan üzenet, amelyek közül az egyik gazdag jelentést tartalmaz, a másik pedig puszta értelmetlenség, valójában egyenló értékú lehet. Roszak úgy fogalmaz, hogy „az információ bármire utalhat, ami kódolható valamilyen csatornán keresztül történó átvitelre, ami összeköt valamely feladót egy címzettel, te- 
kintet nélkül a szemantikai tartalomra” $(1986,13)$. Így lehetóvé válik az információ kvantifikálása, de csak a jelentéséról és a minőségérốl való lemondás árán.

Miután láttuk, hogy az információnak ez a meghatározása képezi az alapját az információs társadalom technológiai és térszemléletú megközelítéseinek (ahol a különféle szempontok alapján kidolgozott mutatók a tárolt, feldolgozott és továbbított információmennyiségekre utalnak), innen továbblépve a jelentésnek a közgazdászok meghatározásaiból való hasonló számúzetéséhez érkezünk. Itt az információ esetleg nem „bitek" formájában jelenik meg, ám szintén megtörténik a szemantikai tulajdonságok kiszúrése - ezúttal az ár közös nevezójével helyettesítve azokat (vö. Arrow 1979).

Az informatikus mérnököket elsôsorban az igen/nem szimbólumok mennyisége, az információval foglalkozó közgazdászokat pedig azoknak az eladhatósága érdekli. Ám amikor a közgazdászok az információ fogalmának értelmezésétól eljutnak az információ méréséig, elvész az a heterogenitás, ami az információ sokrétú jelentéseiból adódik. Az a törekvés, hogy „árcédulát ragasszunk olyan dolgokra, mint például az oktatás, a kutatás és a múvészet” (Machlup 1980, 23), óhatatlanul lemond az információ szemantikai tulajdonságairól. Kenneth Boulding már egy generációval ezelőtt megállapította, hogy „a bit [...] teljesen elvonatkoztat az információ tartalmától [...], és míg rendkívül hasznos a telefonmérnökök számára [...], a társadalmi rendszerrel foglalkozó elméleti szakemberek munkájához olyan mércére van szükségünk, amely figyelembe veszi a jelentést, és ami például egy tinédzser pletykáinak az információértékét meglehetôsen alacsonyan súlyozná, ám a Moszkva és Washington között forródróton lebonyolított kommunikációt elég nagy súllyal venné számításba" (Boulding 1971). Elég különös tehát, hogy a közgazdászok erre, az információ lényegéhez tartozó minőségi problémára olyan mennyiségi megközelítéssel válaszoltak, ami - mivel a költségeken és az árakon alapul - a legjobb esetben is csak „bizonyos kvalitatív becslés lehet” (uo.). Fritz Machlup terminológiáját kölcsönözve: „az értékelhetetlen értékelése” annyit jelent, hogy az információ tartalmát felcseréljük a pénz mérórúdjával. Ily módon képesek vagyunk hatásos statisztikákat készíteni, de az ide vezetố út során elveszítettük azt a képzetünket, hogy az információ szól valamiról (Maasoumi 1987).

Végül - noha a kultúra lényegében arra utaló jelentésekból tevốdik össze, hogy az emberek miért úgy élnek, ahogyan - ugyancsak szembeötló, hogy a szimbólumok nem referenciális jellegét meghirdető és ünneplő posztmodern apostolok munkáiban a kommunikációelmélet összefonódik az információ közgazdasági megközelítésével. Itt szintén az információ bôsége, egy olyan csodálatos információbôség létrejötte fölötti álmélkodással és elragadtatással találkozunk, ami már elvesztette szemantikai tartalmát. A szimbólumok ma mindenütt jelen vannak, és állandóan újra és újra keletkeznek olyannyira, hogy jelentésük mostanra mintegy „,berobbant”, önmagába roskadt, s ennélfogva megszúntek bármit is jelenteni.

Feltétlenül érdemes megemlíteni, hogy az információs társadalom teoretikusai miután az információról alkotott fogalmaikból kiirtották a jelentést, hogy létrehozhassák a növekedés mennyiségi mérôszámait - arra a következtetésre jutnak, hogy az információ rendkívüli módon megnövekedett gazdasági értéke, óriási léptékben folyó „termelése" vagy egyszerúen a körülöttünk örvénylố szimbólumok hatalmas mennyisége következtében a társadalomnak mélységesen jelentésteli változások elébe kell néznie. Más szóval, az információ értékelése nem társadalmi mércékkel történik, hiszen az csu- 
pán létezik, de alkalmazkodnunk kell társadalmi következményeihez. Ez ismerôs helyzet a szociológusok számára, akik gyakran találkoznak olyan állításokkal, hogy bizonyos jelenségek (különösen a technológia és a tudomány) fejlődése a társadalomtól függetlenül megy végbe, ám igen jelentốs társadalmi következményeket von maga után. Ez a felfogás azonban kimutathatóan nem viszi elóbbre a társadalmi változások elemzését (vö. Dickson 1974; Woolgar 1985).

Kétségtelen, hogy jár bizonyos haszonnal, ha általános értelemben képesek vagyunk mennyiségileg kifejezni az információ megnövekedett szerepét a társadalomban, de ez bizonyosan nem nyújt elegendố alapot annak az igazolásához, hogy ennek következtében a társadalom mélyrehatóan megváltozott. Annak a hitelt érdemlő megállapításához, hogy az információs társadalom valójában milyen, és mennyiben különbözik más társadalmi rendszerektól, illetve mennyiben hasonlít azokhoz, feltétlenül tekintetbe kell vennünk az információ jelentését és minôségét. Milyenfajta információk súlya, fontossága növekedett meg? Ki és milyenfajta információkat hoz létre tömegesen, mi célból és milyen következményekkel?

Mint látni fogjuk, az olyan tudósok által adott értelmezések, akik efféle kérdésekból indulnak ki, eltökélten ragaszkodva az információ jelentésének és minơségének a figyelembevételéhez, markánsan különböznek azokétól, akik nem szemantikai, hanem kvantitatív mércéket alkalmaznak. Az elóbbiek különösen szkeptikusak az olyan állításokkal szemben, melyek szerint egy új korszakba való átmenet tanúi vagyunk. Természetesen belátják, hogy ma több információ van jelen, de mivel nem hajlandók ezt a helyzetet az információk tartalmától elvonatkoztatva értékelni, mindig azt kérdezik, hogy milyen információkról van szó, és vonakodnak elfogadni, hogy ennek az információtömegnek a létrehozása az „információs társadalomba” való átmenetet vonta magával.

\section{Konklúzió}

Ebben a fejezetben komoly kétségeket juttattunk kifejezésre az információs társadalom eszméjének érvényességét illetôen. Egyrészt olyan kritériumok sokaságával találkoztunk, amelyekkel mérni próbálják az információs társadalom kialakulását. Késốbb látni fogjuk, hogy vannak olyan gondolkodók, akik - más kritériumokat használva - szintén azt állítják, hogy máris beléptünk az információs társadalomba, vagy annak a küszöbén állunk. Nehezen lehet azonban megbízni egy olyan fogalomban, melynek a védelmezói azt egészen eltéró módokon határozzák meg. Továbbá mindezek a kritériumok, a technológiától a foglalkoztatásban bekövetkezett változásokig és a térbeli jellemzókig - noha elsố pillantásra robusztusnak tûnnek - valójában határozatlanok és pontatlanok, és önmagukban nem alkalmasak annak megállapítására, hogy az információs társadalom vajon már elérkezett-e, vagy elérkezik-e valamikor a jövốben.

Másrészt ismételten azt látjuk, hogy az információs társadalom apostolai az információ szerepében bekövetkezett növekedés kvantitatív mérésére alkalmas mutatók keresésétól eljutnak annak bizonygatásáig, hogy ezek minóségi változásokat jeleznek a társadalmi szervezódésben - ez pedig óhatatlanul mélyen szkeptikussá kell hogy tegye az embert az információs társadalom különféle forgatókönyvei iránt (bár az egy pillanat- 
ra sem vonható kétségbe, hogy az élet kiterjedt „informatizálódása” csakugyan végbement). Az információs társadalom hívei ugyanezt az eljárást alkalmazzák magának az információnak a forgalomban levő meghatározásaiban, amelyekkel alátámasztják nem szemantikai definícióikat. Ezek - ennyi és ennyi bit, ekkora és ekkora gazdasági érték könnyen kvantifikálhatók, s ezáltal megszabadítják az elemzóket annak a terhétól, hogy felvessék a jelentés és az érték minőségi kérdéseit. Ám miközben az információt megfosztják a tartalmától, összeütközésbe kerülnek a szó hétköznapi értelmezésével. Mint látni fogjuk, azoknak a tudósoknak az álláspontja, akik ily módon vezetik le az információk világában végbemenố átalakulásokra vonatkozó magyarázataikat, megint csak radikálisan különbözik azokétól, akik - miközben tudomásul veszik az információrobbanást - kitartanak amellett, hogy sohasem szabad lemondanunk az információ jelentését és rendeltetését firtató kérdésekrôl.

\section{Bibliográfia}

Arrow, Kenneth J. 1979. The Economics of Information. In Dertouzos and Moses 1979. The Computer Age: A Twenty-Year Review, ch. 14, 306-317. Cambridge, MIT Press.

Barron, Iann - Curnow, Ray 1979. The Future with Microelectronics: Forecasting the Effects of Informa. tion Technology. London, Pinter.

Baudrillard Jean 1983a. In the Shadow of the Silent Majorities. New York, Semiotext(e).

Boulding, Kenneth E. 1971 [1966]. The Economics of Knowledge and the Knowledge of Economics. In Lamberton, D. (ed) (1971). Economics of Information and Knowledge, ch. 1,21-36. Penguin Books, Harmondsworth, UK. Elsố megjelenés 1966. American Economic Review, 56 (2). 1-13.

Castells, Manuel 1989. The informational city: Information Technology, Economic Restructuring, and the Urban-Regional Process. Oxford, Blackwell.

Dickson, David 1974. Alternative Technology and the Politics of Technical Change. London, Fontana.

Dordick, Herbert S. - Bradley, Helen G. - Nanus, Burt 1981. The Emerging Network Marketplace. Norwood, NJ, Ablex.

Dordick, Herbert S. - Wang, Georgette 1993. The Information Society: A Retrospective Viere. Newbury Park, CA, Sage.

Drucker, Peter F. 1969. The Age of Discontinuity. London, Heinemann.

Evans, Christopher 1979. The Mighty Micro: the Impact of the Micro-Chip Revolution. London, Gollancz.

Freeman, Christopher - Clark, John - Soete, Luc 1982. Unemployment and Technical Innovation: A Study of Long Waves and Economic Development. London, Pinter.

Freeman, Christopher 1987. Technology Policy and Economic Performance. London, Pinter.

Freeman, Christopher - Perez, Carlota 1988. 'Structural Crises of Adjustment, Business Cycles and Investment Behaviour, in Dosi et al. (eds): Technical Change and Economic Theory. London, Pinter.

Giddens, Anthony 1985. The Nation State and Violence: Volume Two of a Contemporary Critique of Historical Materialism. Cambridge, Polity.

Goddard, John B. 1992 [1991]. New Technology and the Geography of the UK Information Economy. In Robins, K. (ed) 1992. Understanding Information: Business, Technology and Geography, ch. 11, 178-201. London: Belhaven. Első́ megjelenés 1991. Network of Transastions címmel, Times Higher Education Supplement, 22 February, vi. 
Gouldner, Alvin W. (1979) [1978]. The Future of Intellectuals and the Rise of the New Class. London, Macmillan. Elsó megjelenés 1978. The New Class Project címmel. Theory and Society, 6 (2) September, 153-203; 6 (3) November, 343-389.

Hall, Peter - Preston, Paschal 1988. The Carrier Wave: New Information Technology and the Geography of Innovation, 1846-2003. London, Unwin Hyman.

Hepworth, Mark 1989. Geography of the Information Economy. London, Belhaven Press.

Jonscher, Charles 1983. Information Resources and Economic Productivity. Information Economics and Policy. Elsevier, vol. 1(1), 13-35.

Karunaratne, Neil Dias 1986. Issues in Measuring the Information Economy. Journal of Economic Issues, 13 (3), 51-68.

Landes, David S. 1969. The Unbound Prometheus: Technological Change and Industrial Development in Western Europe from 1750 to the Present. London, Cambridge University Press.

Maasoumi, Esfandias 1987. Information Theory. In Eatwell et al. 1987. The New Palgrave: A Dictionary of Economics, London, Macmillan, 846-851.

Machlup, Fritz 1962. The Production and Distribution of Knowledge of the United States. Princeton, NJ, Princeton University Press.

Machlup, Fritz 1980. Knowledge: Its Creation, Distribution, and Economic Significance. Vol. 1: Knowledge and Knowledge Production. Princeton, NJ, Princeton University Press.

Martin, James 1978. The Wired Society. Englewood Cliffs, NJ, Prentice-Hall.

Melody, William H. 1987. Information: An Emerging Dimension of Institutional Analysis. Journal of Economic Issues, 21 (3), September, 1313-1339.

Miles, Ian et al. 1990. Mapping and Measuring the Information Economy. Boston Spa, British Library Research and Development Department.

Miles, Ian 1991. Measuring the Future: Statistics and the Information Age. Future, 23 (9), November, 915-934.

Monk, Peter 1989. Technological Change in the Information Economy. London, Pinter.

Mulgan, Geoff J. 1991. Communication and Control: Networks and the New Economies of Communication. Cambridge, Polity.

Naisbitt, John 1984. Megatrends: Ten New Directions Transforming Our Lives. London, Futura.

Northcott, Jim - Walling, Annette 1989. The Impact of Microelectronics. London, Pinter.

OECD 1986. Trends in the information Economy. ICCP Series, no. 11, 42 pages. Paris, OECD.

OECD 1988. The Telecommunications Industry: Challenges of Structural Change. Paris, OECD.

Office of Technology Assessment 1990. Critical Connections: Communications for the Future. Washington, D. C., U. S. Congress, January.

Perkin, Harold 1990 [1989]. The Rise of Professional Society: Britain since 1880. London and New York, Routledge.

Piore, Michael - Sabel, Charles 1984. Second Industrial Divide. New York, Basic Books.

Porat, Marc Uri 1977a. The Information Economy: Definition and Measurement. (OT Special Publication 77-12 (1), Washington, DC, US Department of Commerce, Office of Telecommunications, May.

Porat, Marc Uri 1977b. The Information Economy: Sources and Methods for Measuring the Primary Information Sector: (Detailed Industry Reports). OT Special Publication 77-12 (2). Washington, DC, US Department of Commerce, Office of Telecommunications, May.

Porat, Marc Uri 1978. Communication Policy in an Information Society. In G. O. Robinson (ed.) 1978. Communications for Tomorrow. New York, Praeger, 3-60.

Poster, Mark 1990. The Mode of Information: Poststructuralism and Social Context. Cambridge, Polity.

Roszak, Theodore 1986. The Cult of Information: the Folklore of Computers and the True Art of Thinking. Cambridge, Lutterworth Press. 
Rubin, Michael Rogers - Huber, Mary Taylor 1986. The Knowledge Industry in the United States, 1960-1980. New Haven, Yale University Press.

Shannon, Claude - Weaver, Warren 1964 [1949]. The Mathematical Theory of Communication. Urbana, University of Illinois Press.

Stonier, Tom 1983. The Wealth of. Information: A Profile of the Post-Industrial Economy. London, Thames Methuen.

Stonier, Tom 1990. Information and the Internal Structure of the Universe: An Exploration into Information physics. Berlin, Springer-Verlag.

Terkel, Studs 1977. Working: People Talk About What They Do All Day and How They Feel About What They Do. Harmondsworth, Penguin, Peregrine Books.

Toffler, Alvin 1980. The Third Wave. London, Collins.

Useem, Michael 1985. The Rise of the Political Manager. Sloan Management Review, 27 (Fall), 15-26.

Useem, Michael - Karabel, Jerome 1986. Pathways to Top Corporate Management. American Socialogical Review, 51 (April), 184-200.

Webster, Frank - Robins, Kevin 1986. Information Technology: a Luddite Analysis. Norwood, NJ, Ablex.

Woolgar, Steve 1985. Why Not a Sociology of Machines? The Case of Sociology and Artificial Intelligence. Sociology, 19 (4), November, 557-572. 